\title{
HPTLC Analysis of Bioactivity Guided Anticancer Enriched Fraction of Hydroalcoholic Extract of Picrorhiza kurroa
}

\author{
Md. Nasar Mallick, ${ }^{1,2}$ Mhaveer Singh, ${ }^{1}$ Rabea Parveen, ${ }^{1}$ Washim Khan, ${ }^{1}$ Sayeed Ahmad, \\ Mohammad Zeeshan Najm, ${ }^{2}$ and Syed Akhtar Husain ${ }^{1}$ \\ ${ }^{1}$ Bioactive Natural Product Laboratory, Department of Pharmacognosy and Phytochemistry, Faculty of Pharmacy, \\ Jamia Hamdard, New Delhi 110062, India \\ ${ }^{2}$ Human Genetics Laboratory, Department of Bioscience, Jamia Millia Islamia, New Delhi 110025, India
}

Correspondence should be addressed to Sayeed Ahmad; sahmad_jh@yahoo.co.in and Syed Akhtar Husain; akhtarhusain2000@yahoo.com

Received 22 May 2015; Revised 6 August 2015; Accepted 19 August 2015

Academic Editor: Kanjoormana A. Manu

Copyright (C) $2015 \mathrm{Md}$. Nasar Mallick et al. This is an open access article distributed under the Creative Commons Attribution License, which permits unrestricted use, distribution, and reproduction in any medium, provided the original work is properly cited.

\begin{abstract}
Objective. Hydroalcoholic extract of Picrorhiza kurroa and its fractions were subjected to in vitro screening for cytotoxicity; further best active fraction (BAF) obtained was tested against Ehrlich ascites carcinoma (EAC) model in Balb/c mice after its quality control analysis. Methods. Cytotoxicities of all the fractions and mother extract of $P$. kurroa were determined, using MTT assay on breast cancer (MCF-7, MDA-MB 231) and cervical cancer (HeLa, SiHa) cell lines. Metabolic fingerprinting was developed using HPTLC with quantification of biomarkers (cucurbitacins B and E; betulinic acid; picrosides 1 and 2; and apocynin) in BAF. The EAC tumorbearing mice were used for in vivo anticancer activity after oral administration $\left(50 \mathrm{mg} \mathrm{Kg}^{-1}\right)$ for 10 days. Results. Cytotoxicity assay of mother extract and its fractions over breast cancer and cervix cancer cell lines showed that dichloromethane (DCM) fraction was most cytotoxic $\left(\mathrm{IC}_{50} 36.0-51.0 \mu \mathrm{g} \mathrm{mL} \mathrm{L}^{-1}\right.$ at $72 \mathrm{~h}$ ). Oral administration of DCM fraction showed significant reduction in tumor regression parameters, viable tumor cell count and restoration of hematological parameters may be due to presence of cucurbitacins $\mathrm{B}$ and E; betulinic acid; picrosides 1 and 2; and apocynin, as compared to the untreated mice of the control group. Conclusion. The DCM fraction of P. kurroa displayed potent anticancer activity and can be further explored for the development of a potential candidate for cancer therapy.
\end{abstract}

\section{Introduction}

Cancer is a major public health problem in many parts of the world. It is currently the second leading cause of death and is expected to surpass heart diseases as the leading cause of death in the next few years [1]. Normal tissue homeostasis is maintained by the two counterparts, namely, cell proliferation and apoptosis [2]. Failure of apoptosis mechanism may result in limitless growth and division of cells. The conventional therapies for cancer include chemo- and radiotherapies mediated by inducing apoptosis or inhibiting proliferation in neoplastic cells [3]. These therapies cause damage to healthy tissues around the tumors $[4,5]$ and also develop resistance by numerous tumors [6]. Researchers have been studying alternatives of cancer therapy by applying potential biological molecules to target neoplastic tumors [7].
Plant-based immunomodulators are nowadays receiving adequate attention and have been evaluated for their active potential to modulate immune responses $[8,9]$. Many of the natural products are in clinical use [10]. Identification of the active components and molecular basis for the action of a traditional medicine is likely to make natural products more acceptable for humans, an approach sometimes referred to as Reverse Pharmacology [11].

Picrorhiza kurroa Royle ex Benth. is a well-known herb of the traditional systems of medicine. It is a perennial herb belonging to the family Scrophulariaceae and found in the Himalayan region at an altitude of $3000-5000 \mathrm{~m}$ [12]. The rhizome of $P$. kurroa is traditionally used for liver disorders and is known to be DNA protective [13] and antioxidant [14]. The rhizome has been reported to contain 
iridoid glycoside like picroside 1, picroside 2 [15-17]; terpene like cucurbitacins [18-20]; and flavonoids like apocynin [21], which are responsible for the anticancer potential of the plant $[18,20,22-33]$. The present investigation was designed to investigate the cytotoxic potential of hydroalcoholic (mother) extract and its bioactivity guided polar and nonpolar compound enriched fractions, in this case, hexane (fat-rich fraction), dichloromethane (DCM) (terpenoidand flavonoid-rich fraction), butanol (glycoside-rich fraction), and acetone (tannins- and phenol-rich fraction), whereas methanol and water contain the remaining polar compounds.

The most cytotoxic fraction, that is, best active fraction (BAF), was further evaluated for in vivo anticancer potential after its quality control analysis, using HPTLC. The contents of picrosides 1 and 2, betulinic acid, cucurbitacins, and apocynin were quantified in BAF since it was terpenoid enriched fraction (DCM). The contents of one flavonoid and 6 terpenoid markers were quantified using newly developed and validated simultaneous HPTLC methods for the first time in any medicinal plant. The anticancer potential of these compounds have already been reported separately $[18,20,22-$ 33]; however no work has been reported till date on terpenoid enriched fraction in totality for P. kurroa.

\section{Materials and Methods}

2.1. Chemicals. RPMI-1640, phosphate buffered saline (PBS), fetal bovine serum (Gibco, USA), trypsin-EDTA, trypan blue, penicillin-streptomycin and amphotericin, and dimethyl sulfoxide (DMSO) were of molecular biology grade. Apocynin, cucurbitacin B and 3-(4,5-dimethylthiazol-2-yl)-2,5diphenyltetrazolium bromide (MTT), and betulinic acid were obtained from Sigma-Aldrich, USA, whereas cucurbitacin $D$, cucurbitacin E, and picroside 1 were obtained from Chromodex, USA. Picroside 2 was provided by Sami Labs Ltd., Bangalore, India, as a gift sample. All the reference standard markers used had more than $98 \%$ purity.

2.2. Plant Material. Plant samples were procured from local drug market of Delhi, India, and the specimen was authenticated by a botanist, Dr. H. B. Singh, Scientist F and Head, Raw Material Herbarium and Museum, NISCAIR, New Delhi (Ref. NISCAIR/RHMD/Consult/-2010-11/1563/161/27/10-10).

2.3. Hydroalcoholic Extract (Mother Extract) and Its Fractionation. The $500 \mathrm{gm}$ of powdered P. kurroa rhizome was extracted with $70 \%$ alcohol in Reflux extractor for five hours on water bath and filtered. The filtrate was evaporated to dryness under reduced pressure. The hydroalcoholic (mother) extract thus obtained was suspended in double distilled water $(1 \mathrm{gm} / 10 \mathrm{~mL})$ and sonicated for $15 \mathrm{~min}$ at $45^{\circ} \mathrm{C}$. Prepared aqueous suspension was partitioned with equal proportions of hexane, DCM, and n-butanol (thrice each). The aqueous suspension left after partitioning was evaporated to dryness and the residue was sonicated further with acetone and methanol separately for $20 \mathrm{~min}$, thrice each. The remaining residue and solvent fractions obtained were evaporated to dryness under reduced pressure. The extractive values and \% yields of different fractions were calculated and stored at $4^{\circ} \mathrm{C}$ for bioactivity and quantitative analysis.

2.4. Cell Line and Cell Culture. All cell lines (MCF-7, SiHa, Hela, and MDA-MB 231) used in the study were obtained from National Centre for Cell Science (NCCS) at Pune, India. The cell lines were grown as monolayer cultures in RPMI1640 media with $10 \%$ foetal calf serum (FCS) and 1\% PSA (penicillin, streptomycin, and amphotericin) in a humidified atmosphere of $5 \% \mathrm{CO}_{2}$ at $37^{\circ} \mathrm{C}$.

2.5. Cytotoxicity Assay of Picrorhiza Extract and Its Fractions. The cytotoxicity assays of mother extract and its hexane, DCM, n-butanol, acetone, methanol, and water fractions were carried out to find out the best active fraction (BAF). The stock solution was prepared by dissolving $500 \mathrm{mg}$ of each extract/fraction in dimethyl sulfoxide (DMSO) and volume was made up to $10 \mathrm{~mL}$ in volumetric flask, separately. These solutions were passed through $0.45 \mu \mathrm{m}$ membrane filter and stored at $4^{\circ} \mathrm{C}$ until used. These were diluted fifty times using RPMI-1640 media ( $1 \mathrm{~mL}$ to $50 \mathrm{~mL}$ ) to get a concentration of $1000 \mu \mathrm{g} \mathrm{mL}^{-1}$ of every extract/fractions. Further, these solutions were passed through $0.22 \mu \mathrm{m}$ membrane filter in aseptic condition before using for in vitro activity on different cell lines. Similarly, DMSO control was also prepared and used for every cell line.

In brief, MTT [3-(4,5-dimethylthiazole-2-yl)-2,5-diphenyl tetrazolium bromide] assay was performed on MCF-7, SiHa, HeLa, and MDA-MB 231 cell lines [34]. $1 \times 10^{4}$ cells were seeded on 96-well plates supplemented with $100 \mu \mathrm{L}$ of the respective culture media for a period of $24 \mathrm{~h}$ at $37^{\circ} \mathrm{C}$. It was then substituted by $100 \mu \mathrm{L}$ of fresh media containing varying concentrations of the extract/fractions (3.9, 7.8, 15.6, $31.2,62.5,125,250$, and $500 \mu \mathrm{g} \mathrm{mL}^{-1}$ ). The plates were again incubated for 24,48 , and $72 \mathrm{~h}$, separately at $37^{\circ} \mathrm{C}$, by changing fresh media containing extracts/fractions every $24 \mathrm{~h}$. After incubation period media were removed and fresh media added; $20 \mu \mathrm{L}$ of MTT reagent prepared in respective media $\left(5 \mathrm{mg} \mathrm{mL}^{-1}\right)$ was then added to all the wells. This was followed by incubation for $3 \mathrm{~h}$. After seeing purple color precipitation which was very well visible under microscope, media were carefully discarded for solubilization of formazan crystals (MTT formazan). Further, $100 \mu \mathrm{L}$ of DMSO was added to each well and cells were incubated in dark at room temperature for $1 \mathrm{~h}$. The purple color developed was measured at $570 \mathrm{~nm}$ by a microplate reader (Bio-Rad, USA). The percentage of cytotoxicity of these extracts was calculated by using the following formula:

$$
\left\{\frac{A_{c}-A_{s}}{A_{c}}\right\} \times 100,
$$

where $A_{c}$ is the absorbance of the control and $A_{s}$ is the absorbance of the sample. 


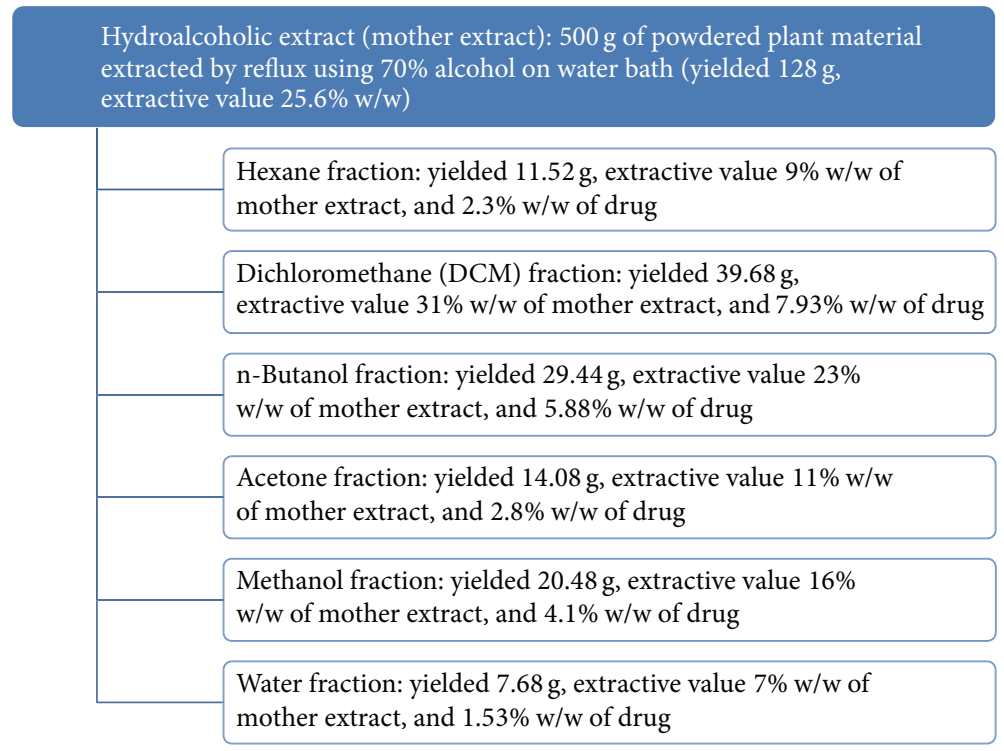

Figure 1: Schematic representation of extraction and fractionation of hydroalcoholic extract (mother extract) of Picrorhiza kurroa showing extractive values.

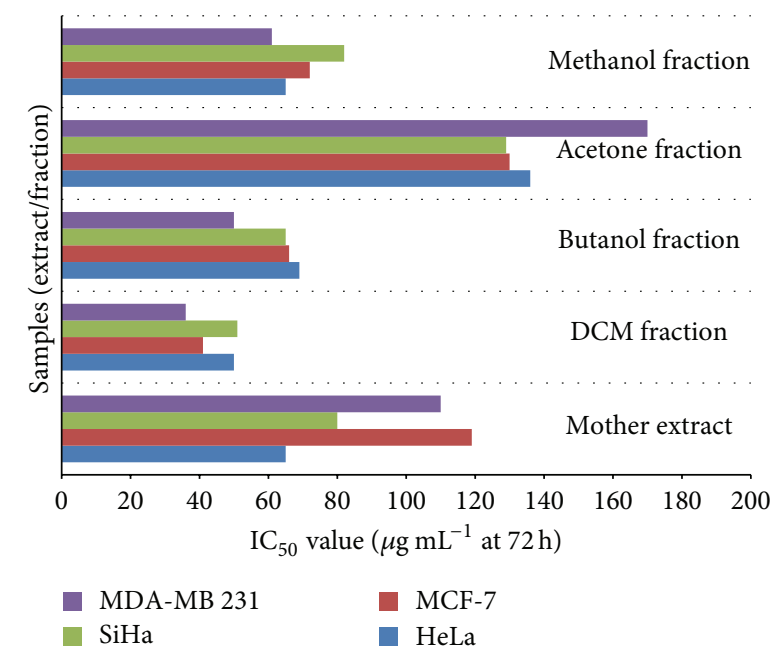

FIgURE 2: Bar graph showing $\mathrm{IC}_{50}$ of mother extract, DCM fraction, $\mathrm{n}$-butanol fraction, acetone fraction, and methanol fraction at $72 \mathrm{~h}$ in HeLa, SiHa, MCF-7, and MDA-MB 231 cell lines.

2.6. HPTLC Analysis. HPTLC fingerprints of mother extracts and their fractions like hexane, DCM, n-butanol, acetone, methanol, and water were carried out for their quality control and determination of number of compounds present in them. Presence of picrosides [15-17], cucurbitacins [18-20], apocynin [21], and their anticancer potential [18, 20, 22-34] has already been reported and hence simultaneous analysis of these compounds in the BAF was carried out using newly developed HPTLC methods. These methods were developed as per ICH guidelines, similar to several methods reported by the Laboratory for Quality Control of Herbal Drugs and Botanicals [35, 36].
2.7. Sample Preparation and Chromatographic Conditions. The dried mother extract and fractions $(100 \mathrm{mg}$ each) of $P$. kurroa were reconstituted using HPLC grade methanol in a $10 \mathrm{~mL}$ volumetric flask to get $10 \mathrm{mg} \mathrm{mL}^{-1}$ solution. These were sonicated and filtered through $0.22 \mu \mathrm{m}$ syringe filter before being used for HPTLC analysis. The samples were applied in triplicate $(8.0 \mu \mathrm{L}$ each) and the width of the track was kept to $4.0 \mathrm{~mm}$ on precoated silica gel $60 \mathrm{~F}_{254}$ plates (E. Merck, $0.20 \mathrm{~mm}$ thickness), using Linomat V (HPTLC sample applicator). Linear ascending development was carried out in $10 \times 20 \mathrm{~cm}$ twin trough-glass chamber (Camag, Muttenz, Switzerland). The optimized chamber saturation time for solvent system was $30 \mathrm{~min}$ at $25^{\circ} \mathrm{C}$ and relative humidity of $60 \%$. The chromatogram was developed up to $85 \%$ of total TLC plate height. Developed chromatograms were scanned at $254 \mathrm{~nm}$ for DCM extract without derivatization but at $520 \mathrm{~nm}$ for other extracts after derivatization with anisaldehyde sulphuric acid. The wavelengths for fingerprinting were selected by multiwavelength scanning showing the highest number of peaks.

The quantification of cucurbitacins B, D, and E; betulinic acid; picrosides 1 and 2; and apocynin was carried out in three different sets of chromatography for quality control of BAF.

Stock solutions of cucurbitacins B, D, and E; betulinic acid; picrosides 1 and 2; and apocynin were prepared in HPLC grade methanol to get a known concentration of $500 \mu \mathrm{g} \mathrm{mL}{ }^{-1}$. In the first set, the stock solutions of cucurbitacins $\mathrm{B}, \mathrm{D}$, and $\mathrm{E}$ were mixed in equal volume to get cucurbitacin standard (STC, $166.66 \mu \mathrm{g} \mathrm{mL} \mathrm{L}^{-1}$ each). It was applied in triplicate in different volumes $(0.1-10 \mu \mathrm{L})$ on HPTLC plate and eluted using toluene : ethyl acetate: formic acid, $60: 40: 0.5, \mathrm{v} / \mathrm{v} / \mathrm{vas}$ solvent system. The second set of chromatography was done for quantification of picrosides 1 and 2 and apocynin; similarly equal volumes of all three 


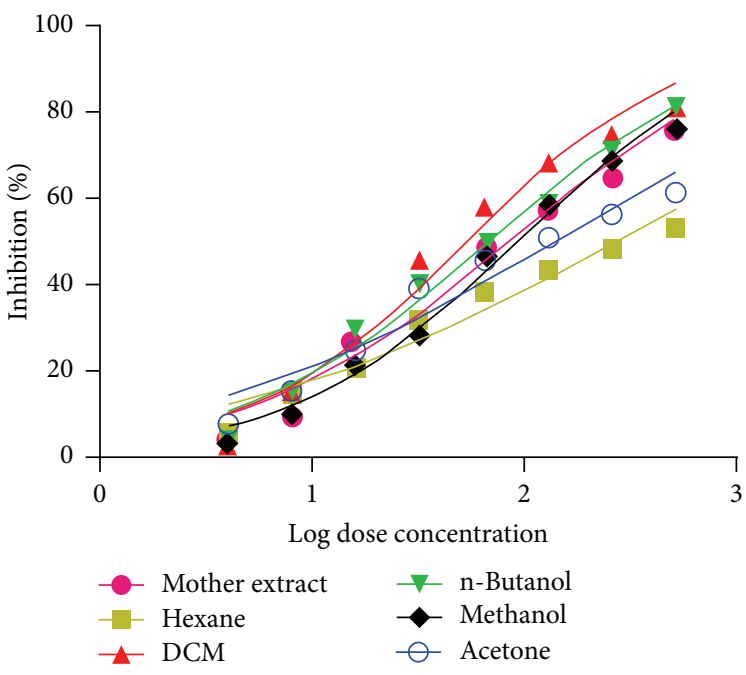

(a)

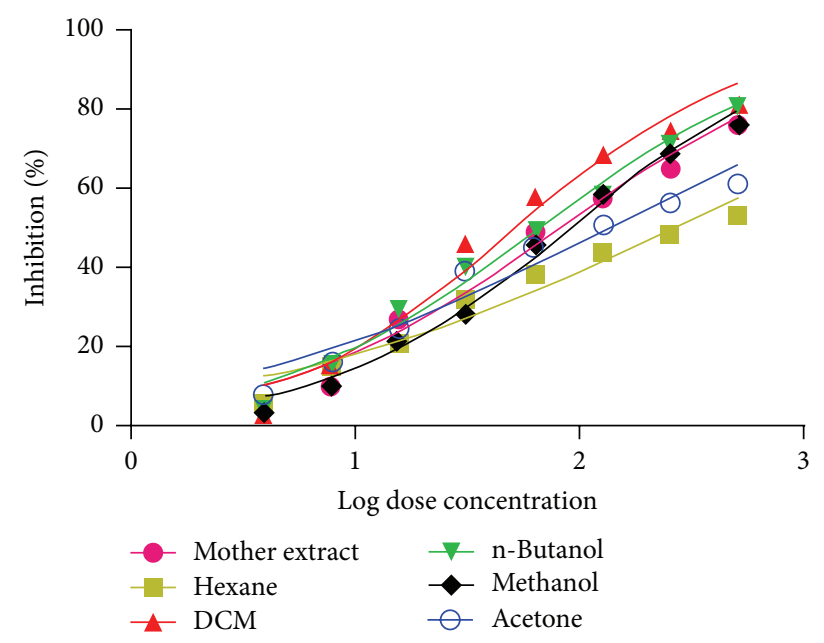

(c)

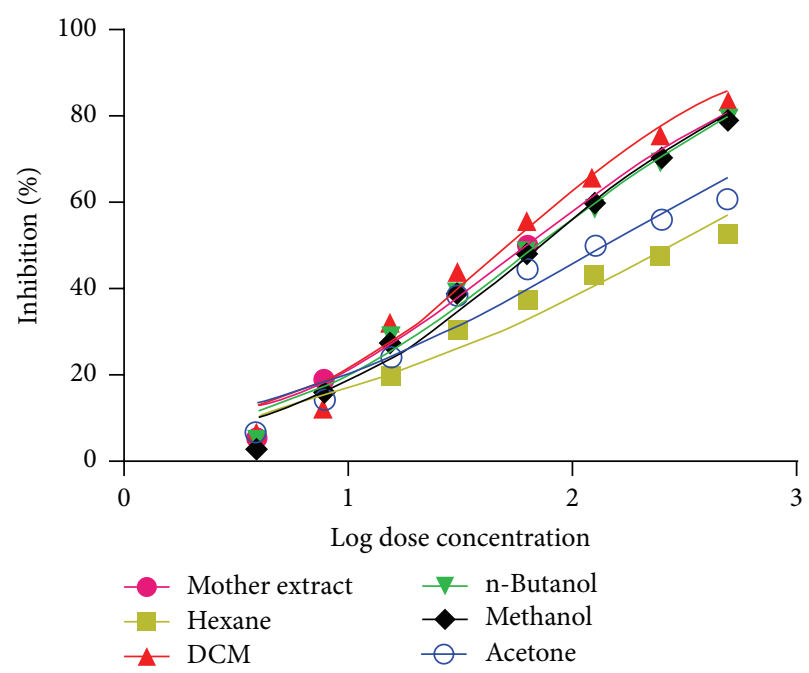

(b)

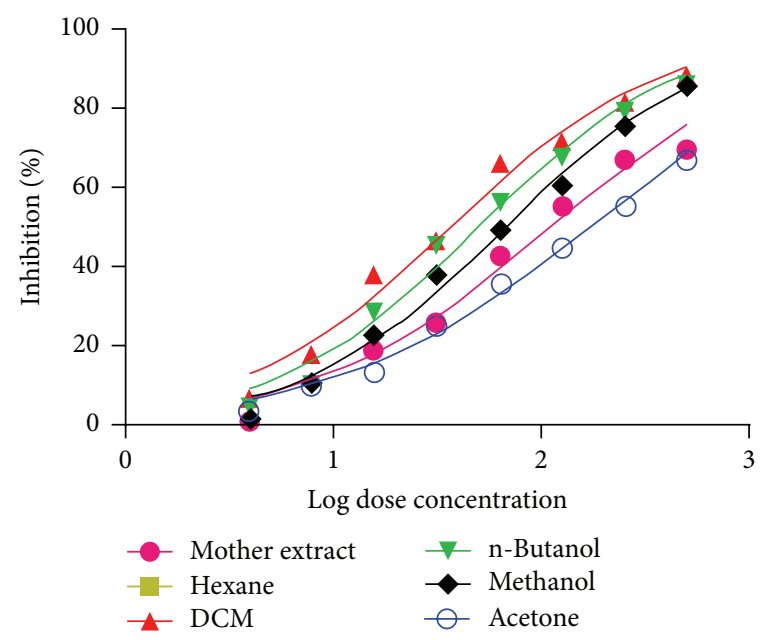

(d)

Figure 3: Dose response curve showing log dose concentration versus percent inhibition of extract/fractions of $P$. kurroa on cell lines at $72 \mathrm{~h}$. (a) HeLa, (b) SiHa, (c) MCF-7, and (d) MDA-MB 231.

TABLE 1: HPTLC fingerprint data of mother extract and different fractionation of $P$. kurroa.

\begin{tabular}{|c|c|c|c|}
\hline Extracts & Solvent system & Visualization & Number of major spots and $R_{f}$ values \\
\hline $\begin{array}{l}\text { Hydroalcoholic } \\
\text { extract/mother } \\
\text { extract }\end{array}$ & $\begin{array}{l}\text { Methanol : ethyl acetate : formic } \\
\text { acid }(0.5: 5: 1, \mathrm{v} / \mathrm{v} / \mathrm{v})\end{array}$ & $\begin{array}{l}\text { Anisaldehyde sulphuric } \\
\text { acid at } 520 \mathrm{~nm}\end{array}$ & (07) $0.11,0.16,0.25,0.35,0.47,0.63,0.96$. \\
\hline Hexane fraction & $\begin{array}{l}\text { Toluene : ethyl acetate }(1.8: 0.1 \text {, } \\
\mathrm{v} / \mathrm{v})\end{array}$ & $\begin{array}{l}\text { Anisaldehyde sulphuric } \\
\text { acid at } 520 \mathrm{~nm}\end{array}$ & (09) $0.09,0.13,0.19,0.24,0.38,0.48,0.53,0.61,0.87$ \\
\hline DCM fraction & $\begin{array}{l}\text { Toluene : ethyl acetate : formic } \\
\text { acid }(1.5: 0.6: 0.1, \mathrm{v} / \mathrm{v} / \mathrm{v})\end{array}$ & At $254 \mathrm{~nm}$ & (08) $0.11,0.16,0.24,0.28,0.44,0.53,0.66,0.77$ \\
\hline n-Butanol fraction & $\begin{array}{l}\text { Methanol : ethyl acetate : formic } \\
\text { acid }(0.5: 5: 1, \mathrm{v} / \mathrm{v} / \mathrm{v})\end{array}$ & $\begin{array}{l}\text { Anisaldehyde sulphuric } \\
\text { acid at } 520 \mathrm{~nm}\end{array}$ & (09) $0.10,0.13,0.18,0.20,0.23,0.27,0.32,0.37$. \\
\hline Acetone fraction & $\begin{array}{l}\text { Methanol : ethyl acetate : formic } \\
\text { acid }(0.5: 5: 1, \mathrm{v} / \mathrm{v} / \mathrm{v})\end{array}$ & $\begin{array}{l}\text { Anisaldehyde sulphuric } \\
\text { acid at } 520 \mathrm{~nm}\end{array}$ & (07) $0.08,0.14,0.24,0.34,0.45,0.62,0.80$. \\
\hline Methanol fraction & $\begin{array}{l}\text { Methanol : ethyl acetate : formic } \\
\text { acid }(0.5: 5: 1, \mathrm{v} / \mathrm{v} / \mathrm{v})\end{array}$ & $\begin{array}{l}\text { Anisaldehyde sulphuric } \\
\text { acid at } 520 \mathrm{~nm}\end{array}$ & (08) $0.08,0.13,0.22,0.33,0.43,0.60,0.67,0.79$ \\
\hline
\end{tabular}




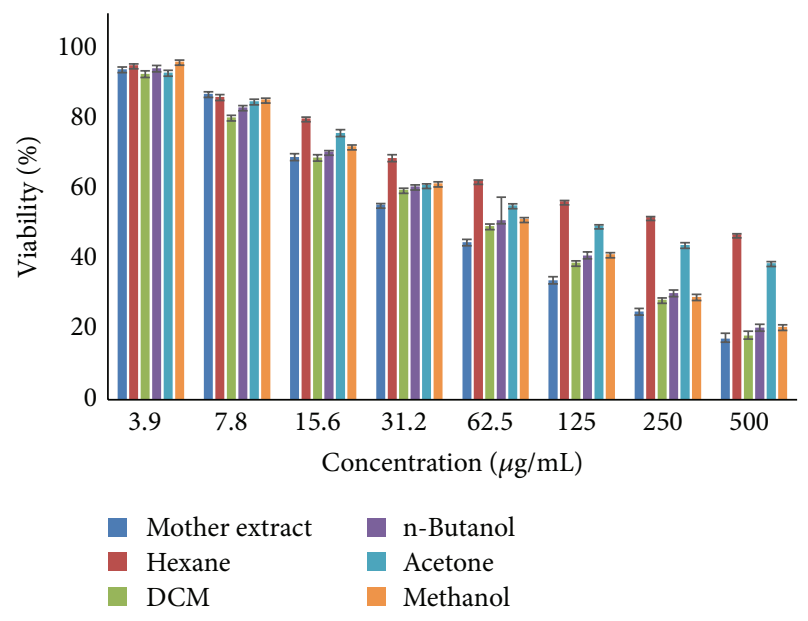

(a)

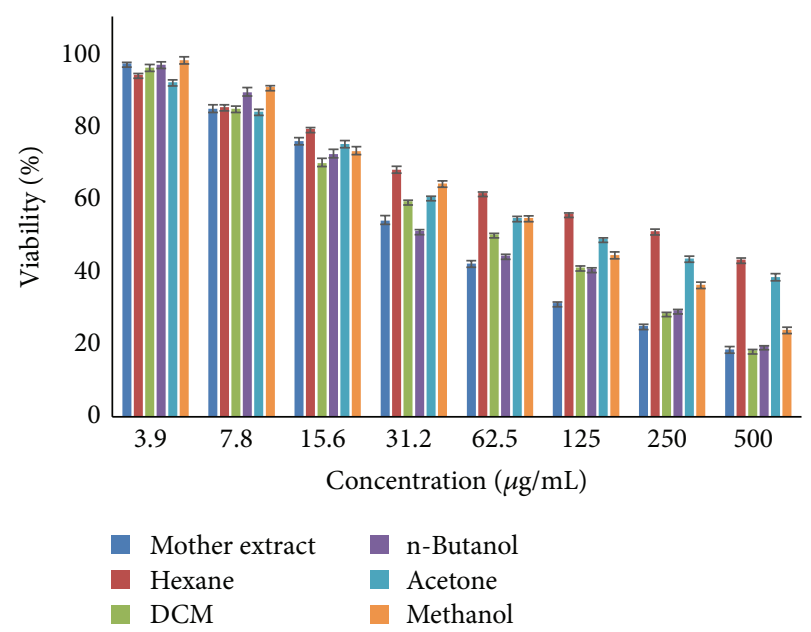

(c)

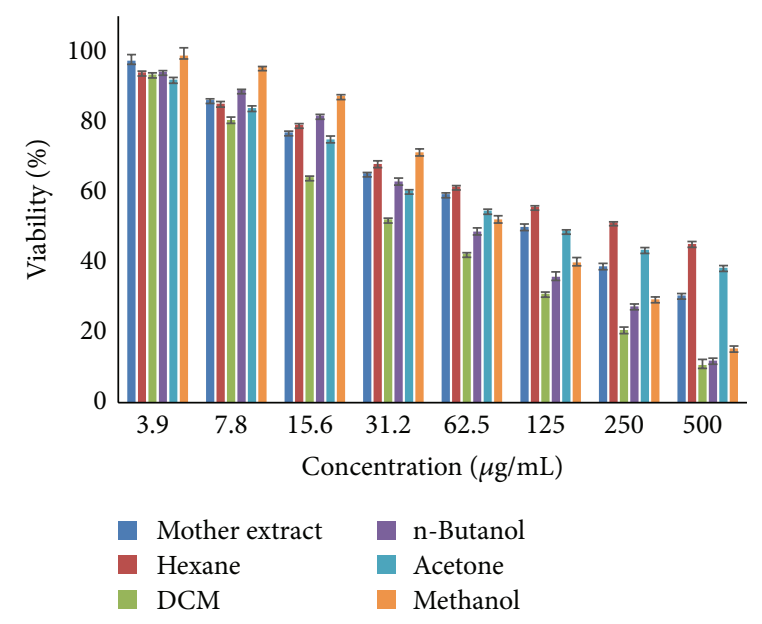

(b)

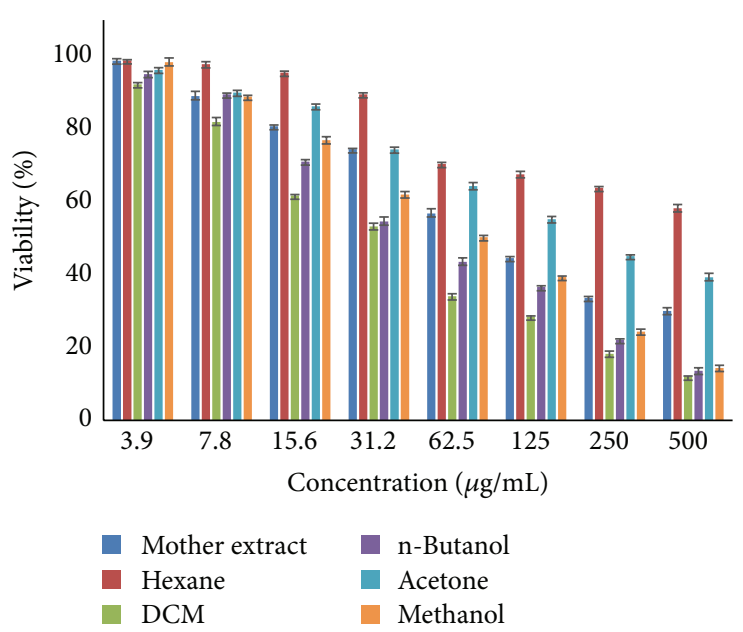

(d)

FIGURE 4: Bar graph showing concentration of extract/fractions of $P$. kurroa versus percent cell viability at 72 h. (a) HeLa, (b) MCF-7, (c) SiHa, and (d) MDA-MB 231 cell lines.

stock standards were mixed to get the picroside and apocynin standards (STPA, $166.66 \mu \mathrm{g} \mathrm{mL}^{-1}$ each). This was also applied in triplicate in different volumes $(0.1-10 \mu \mathrm{L})$ on HPTLC plate and eluted and toluene : ethyl acetate : methanol : formic acid, $40: 50: 10: 0.2, \mathrm{v} / \mathrm{v} / \mathrm{v} / \mathrm{v}$, was used as solvent system. In the third set of chromatography, betulinic acid (STB) was applied as such $\left(500 \mu \mathrm{g} \mathrm{mL}^{-1}\right)$ in triplicate in different volumes $(0.1-10 \mu \mathrm{L})$ and eluted, using same solvent as used for cucurbitacin. The sample (BAF, $8.0 \mu \mathrm{L}$ each) was applied in triplicate on every plate with the same chromatographic conditions as mentioned above. The quantification was done by scanning the developed chromatograms at $240 \mathrm{~nm}$ for cucurbitacins (without derivatization), at $595 \mathrm{~nm}$ for betulinic acid, and at $500 \mathrm{~nm}$ for picrosides and apocynin after derivatization with anisaldehyde sulphuric acid reagent.

2.8. Validation of the Method Developed. The newly developed HPTLC method was optimized and validated as per the ICH guidelines for calibration, linearity, precision, accuracy, robustness, specificity, LOD, and LOQ, similar to the other methods reported from this laboratory $[35,36]$.

2.9. Calibration Curve and Linearity. Different volumes (0.1$10 \mu \mathrm{L} \mathrm{spot}^{-1}$ ) of the standard solutions (STC, STPA, and STB) were separately spotted on TLC plates (in triplicate) to obtain different concentrations of cucurbitacins, picrosides, apocynin (16.7-1666.6 ng spot ${ }^{-1}$ ), and betulinic acid (250$2500 \mathrm{ng} \mathrm{spot}^{-1}$ ) for calibration plots. The data of peak area versus drug concentration were treated by linear least square regression and the concentration range showing best regressions was considered for linearity [35].

2.10. Precision. Precision of the proposed method was obtained by repeatability and intermediate precision. Interday and intraday precisions were done by preparing and applying three different concentrations of standards (in triplicate) on the same day and on three different days, respectively. The interanalyst precision was carried out by repeating the same procedure using different systems of the same make and 


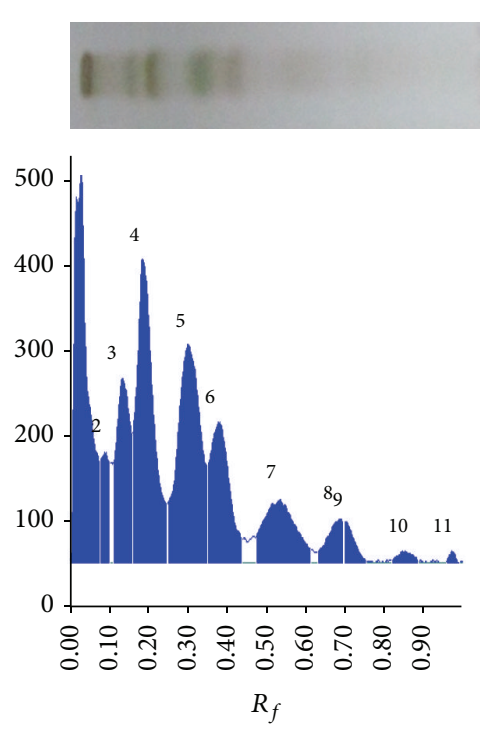

(a)

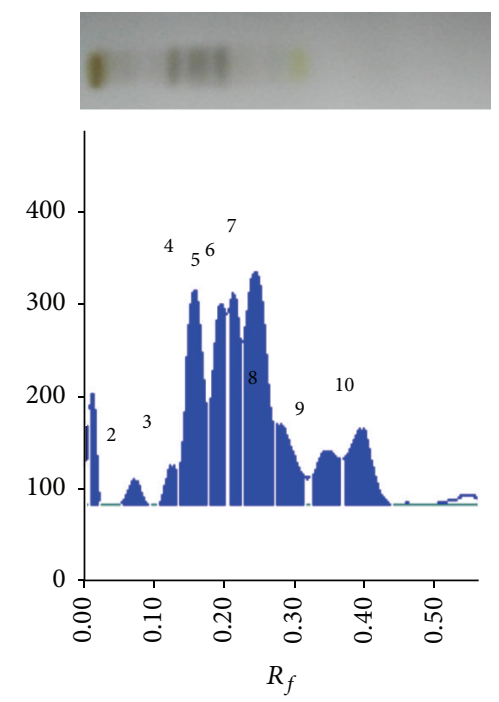

(d)

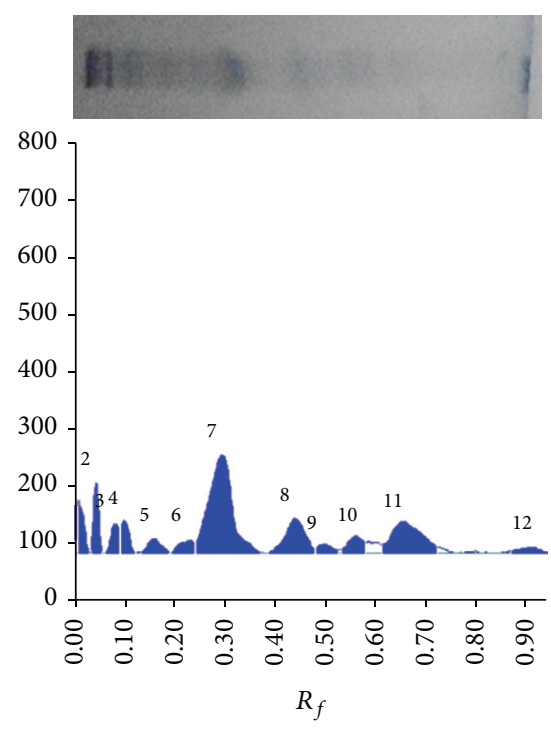

(b)
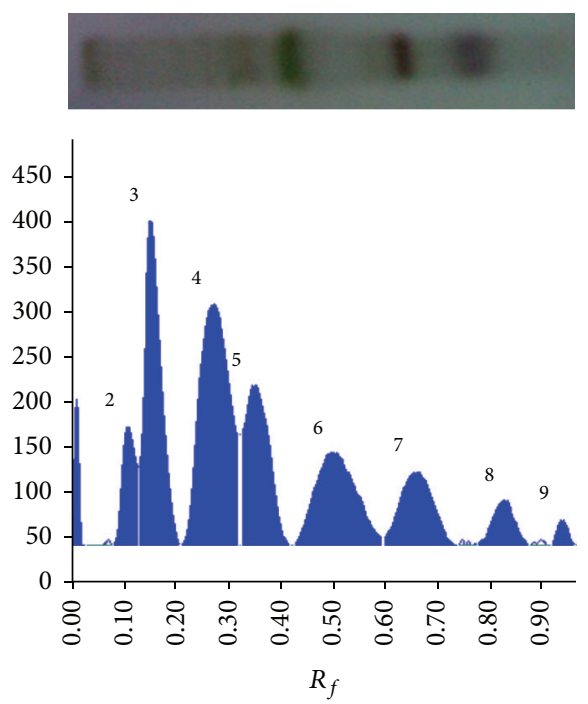

(e)

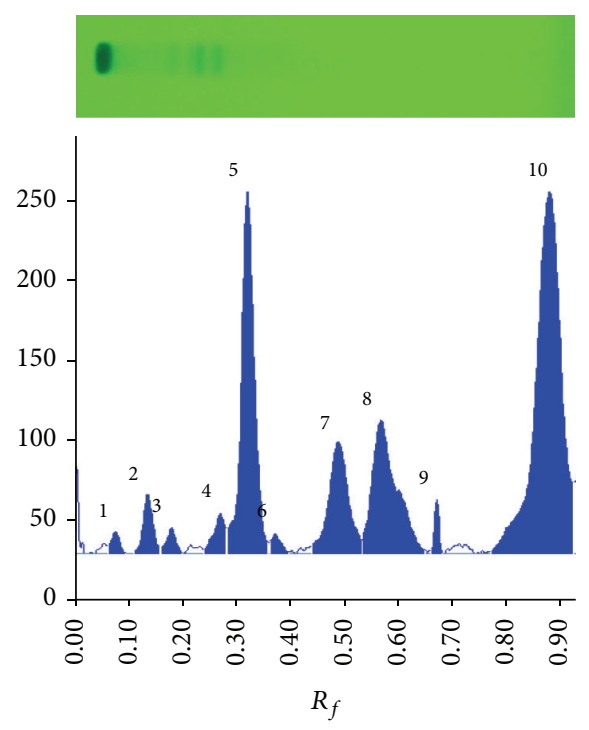

(c)

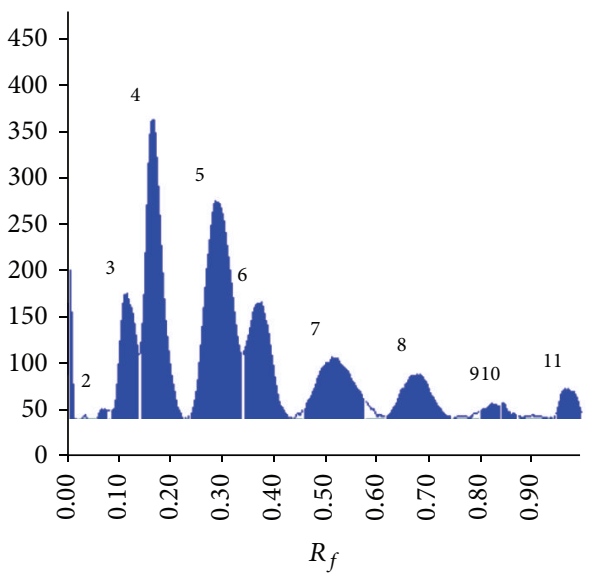

(f)

FIGURE 5: Developed TLC plates and HPTLC chromatogram. hydroalcoholic extract (a), hexane fraction (b), DCM fraction at $254 \mathrm{~nm}$ underivatized (c), n-butanol fraction (d), acetone fraction (e), and methanol fraction (f) of P. kurroa at 520 nm after derivatization with anisaldehyde sulphuric acid showing peaks of separated compounds.

by different analysts, respectively. Precision studies were done at three different concentration levels. The method precision and intermediate precision were determined and reported in terms of $\%$ RSD [36].

2.11. Robustness of the Method. Robustness of the analytical procedure is a measure of its capacity to remain ineffective by small, but deliberate, variations in the method parameters and provide an indication of its reliability during normal usage. Robustness of the method was achieved by introducing small changes in the compositions of mobile phase and detection wavelength. The effect on the results was examined as \% RSD [35].
2.12. Specificity. The specificity of the method was ascertained by analysing standard drug and sample. The detection of spots for cucurbitacins $\mathrm{B}, \mathrm{D}$, and $\mathrm{E}$; betulinic acid; picrosides 1 and 2; and apocynin in BAF was confirmed by comparing $R_{f}$ and spectra of spots with those of the standards. The peak purity was assessed by comparing the spectra at three different levels, that is, peak start, peak apex, and peak end positions of the spot [36].

\subsection{Limit of Detection (LOD) and Limit of Quantification} (LOQ). The LOD was expressed as LOD $=3.3 \sigma / \mathrm{slope}$, whereas LOQ was expressed as LOQ $=10 \sigma /$ slope of calibration curve [36]. 


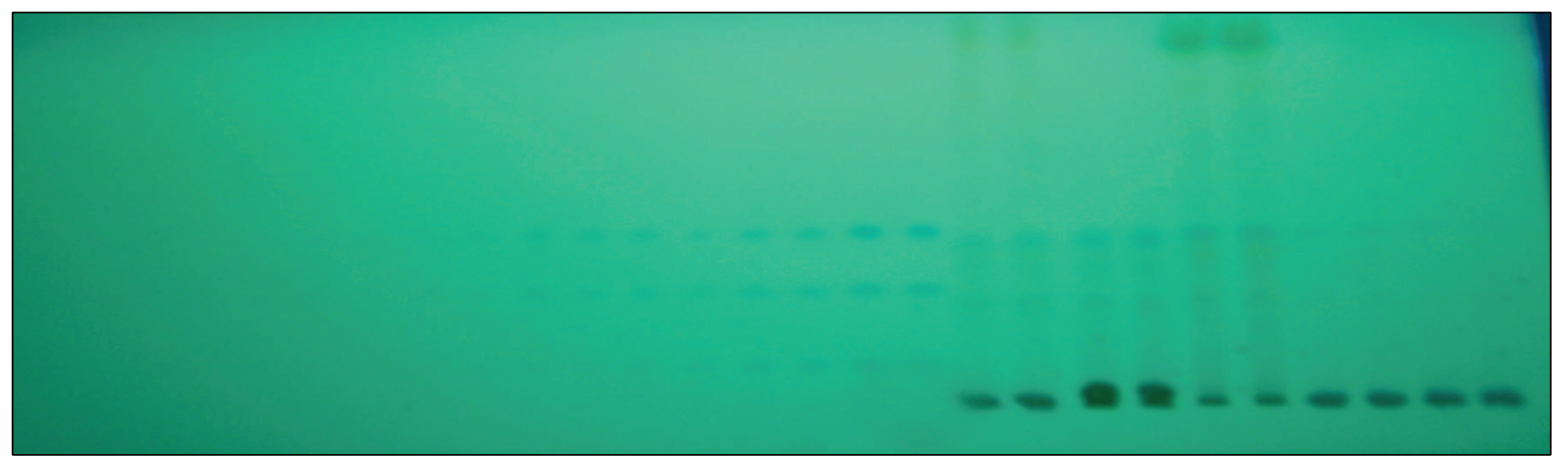

(a)

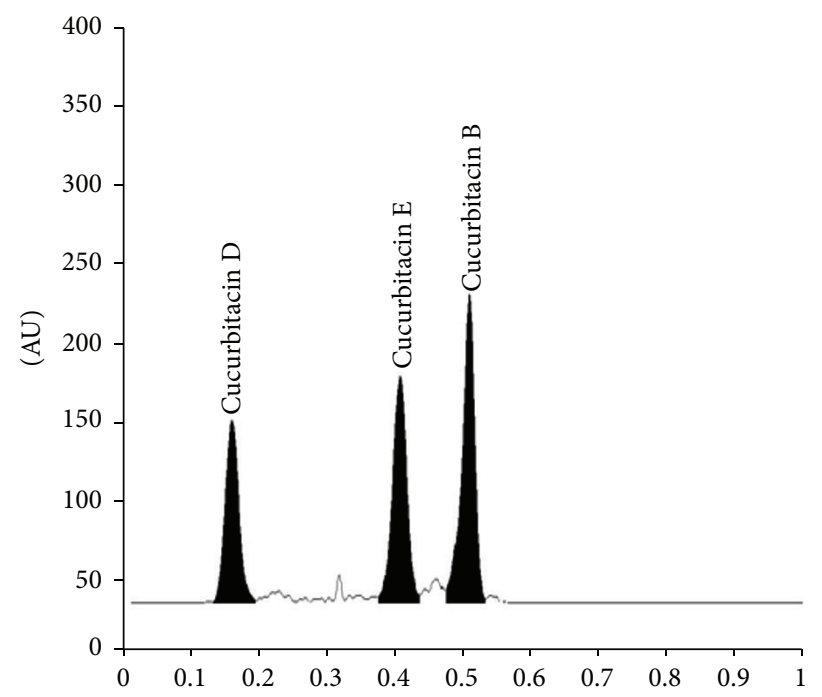

(b)

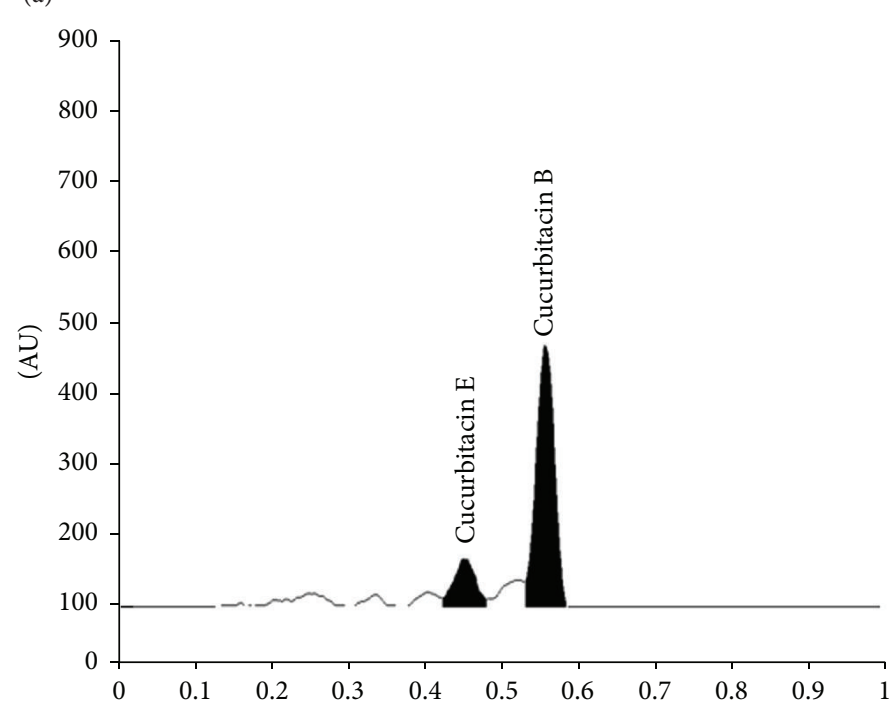

(c)

FIGURE 6: Developed HPTLC plate at $240 \mathrm{~nm}$ showing spots of cucurbitacins B, D, and E at different concentrations. Standard and in sample (a), HPTLC chromatograms of standard cucurbitacins B, D, and E (b), and sample (c).

2.14. Accuracy as Recovery. In analytical methods the closeness of test results obtained by that method to the theoretical value is called the accuracy. The standard addition method was used by spiking at four different concentration levels, that is, $0,50,100$, and $150 \%$, of analyte in preanalyzed samples [36].

2.15. Analysis of Cucurbitacins B, D, and E; Betulinic Acid; Picrosides 1 and 2; and Apocynin in BAF. The newly developed method was applied for simultaneous estimation of cucurbitacins B, D, and E and betulinic acid as well as picrosides 1 and 2 and apocynin in DCM fraction of $P$. kurroa. The samples were applied in triplicate on HPTLC plates with standard and the contents of metabolites were analyzed, using regression equations obtained from calibration plots, and expressed as $\% \mathrm{w} / \mathrm{w}$.

2.16. In Vivo Antitumor Activity on Balb/c Mice. The in vivo study was performed to carry out the anticancer activity of DCM fraction of hydroalcoholic (mother) extract of $P$. kurroa after oral administration to female Balb/c mice (25$30 \mathrm{~g}$ ) as per the standard protocol [37-39]. The dose of DCM fraction was decided as per its extractive value equivalent to the dose of the drug ( $4.0 \mathrm{~g}$ per day) [37]. Animals were obtained from Central Animal Facility of Jamia Hamdard. This study was approved by and carried out under strict guidelines of Institutional Animal Ethics Committee (IAEC) of Jamia Hamdard, constituted by Committee for the Purpose of Control and Supervision of Experiments on Animals (CPCSEA, registration number 173/CPCSEA, 28 January 2000) of Ministry of Environment and Forest, Government of India (protocol approval number 915/22.10.2012).

2.17. Animals and Treatment Schedule. Twenty-four female $\mathrm{Balb} / \mathrm{c}$ mice were procured from the central animal house facility of the University (Jamia Hamdard) and divided into four groups of six animals each. Group I, receiving 1\% carboxymethyl cellulose (CMC) $(0.2 \mathrm{~mL}$ oral, once daily for 10 days), served as control (nontumor mice, untreated); other groups received Ehrlich ascites carcinoma (EAC) cells $\left(2 \times 10^{6}\right.$ cells/mouse, intraperitoneally (i.p.)), which was obtained generously from Cell Culture Laboratory of Dr. Dwarka Nath, INMAS, New Delhi. Group II served as toxic control (tumor induced, untreated mice), whereas group 


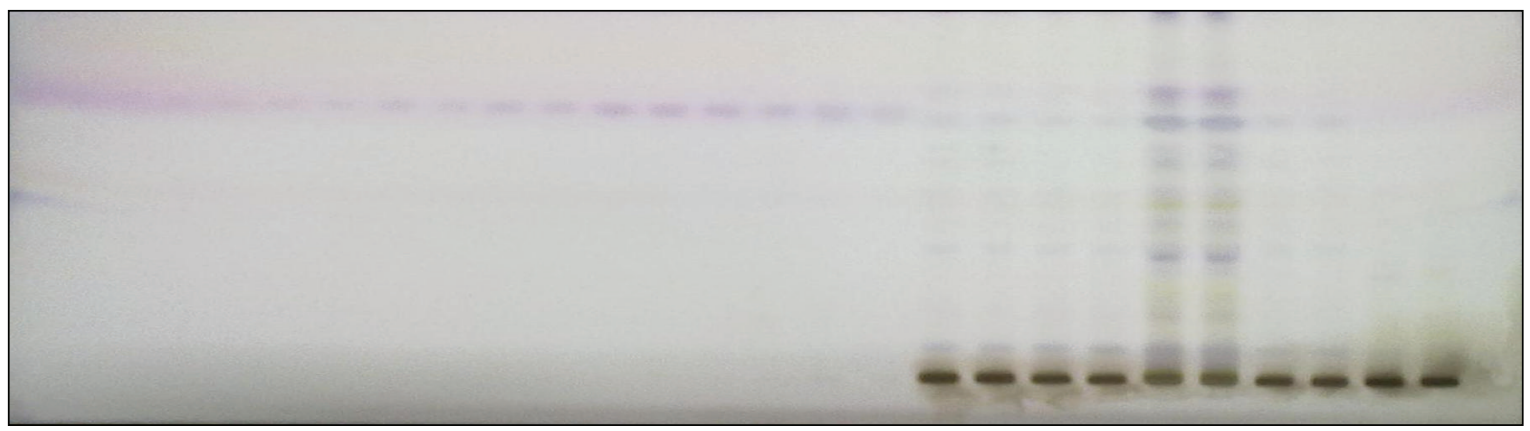

(a)

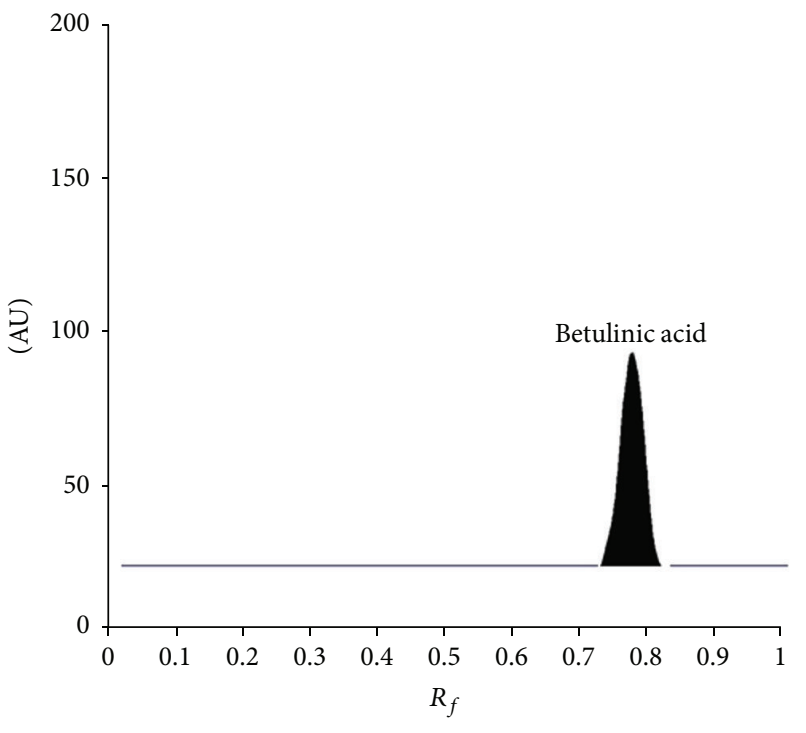

(b)

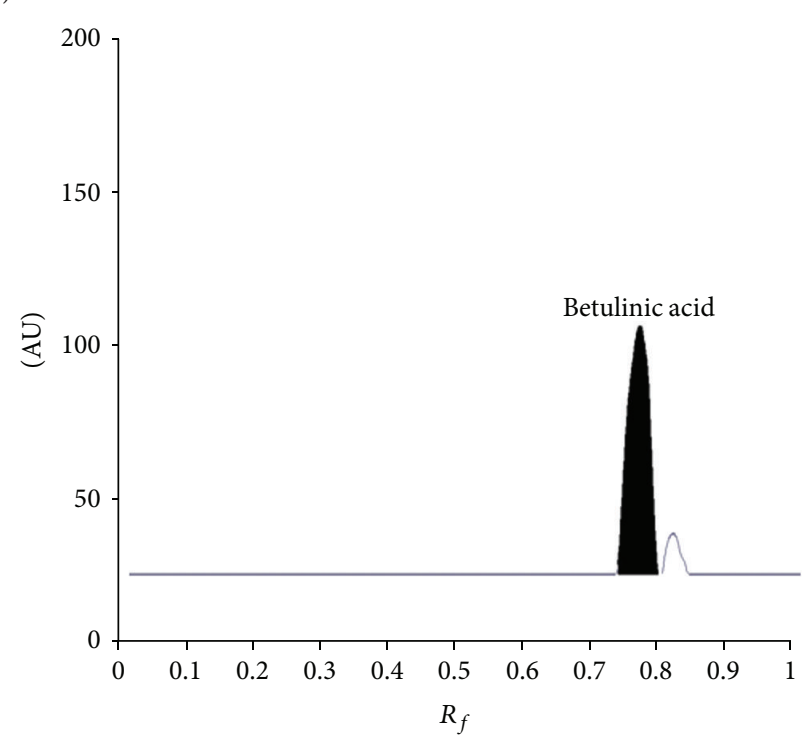

(c)

Figure 7: Developed HPTLC plate at $595 \mathrm{~nm}$ showing spots of betulinic acid at different concentrations. Standard and in sample (a), HPTLC chromatograms of standard betulinic acid (b), and sample (c).

III received suspension of DCM fraction $\left(50 \mathrm{mg} \mathrm{Kg}^{-1}\right.$ body weight, orally) once daily for $10 \mathrm{~d}$. However, group IV received standard 5-fluorouracil $\left(20 \mathrm{mg} \mathrm{Kg}^{-1}\right.$ body weight, i.p.) once daily for $10 \mathrm{~d}$, after $24 \mathrm{~h}$ of EAC transplantation [38-40].

\subsection{Analysis of Tumor Regression and Hematological Param-} eters after Oral Administration of DCM Fraction. The tumor regression parameters (tumor volume, packed cell volume, tumor weight, and viable and nonviable cell count) were analyzed after administration of last dose. The mice from each group were kept fasting for $18 \mathrm{~h}$ and blood samples were collected in ethylenediaminetetraacetic acid coated vials following anesthesia with ketamine-xylazine by cardiac puncture for the estimation of haematological toxicity. The animals were then sacrificed by cervical dislocation for the study of antitumor activity. Hematologic analysis was carried out using an automated hematologic analyzer (MS9 Differential Cell Counter 3 Part, HD Consortium, India). The mice were dissected and the peritoneal cavity was used to collect the ascetic fluid. The tumor volume was measured in a graduated centrifuge tube (in $\mathrm{mL}$ ). The packed cell volume
(PCV) was determined by centrifuging the ascetic fluid at $10,000 \mathrm{rpm}$ for 5 minutes in centrifuge tube. This separates the fluid into layers. The volume of packed cells divided by the total volume of the ascetic fluid gives the \% PCV. The tumor weight was calculated by measuring the weight (in gm) of mice before and after the collection of ascetic fluid from peritoneal cavity. The ascetic fluid was diluted 20 times with PBS, after which a drop of diluted cell suspension was placed on Neubauer's chamber and the number of cells was counted. The viability and nonviability of cells were checked by trypan blue assay. The viable and nonviable cells were counted as

$$
\text { Cell count }=\frac{[\text { Number of cells } \times \text { Dilution factor }]}{\text { Area } \times \text { Thickness of the liquid film }} \text {. }
$$

The hematological parameters like total white blood cells (WBCs), red blood cell (RBC), lymphocytes (LYM), platelet (PLT), hematocrit (HCT), hemoglobin (HGB), mean corpuscular haemoglobin concentration (MCHC), mean corpuscular volume (MCV), mean corpuscular hemoglobin $(\mathrm{MCH})$, red blood cell distribution width (RDW), and MID cells (less 


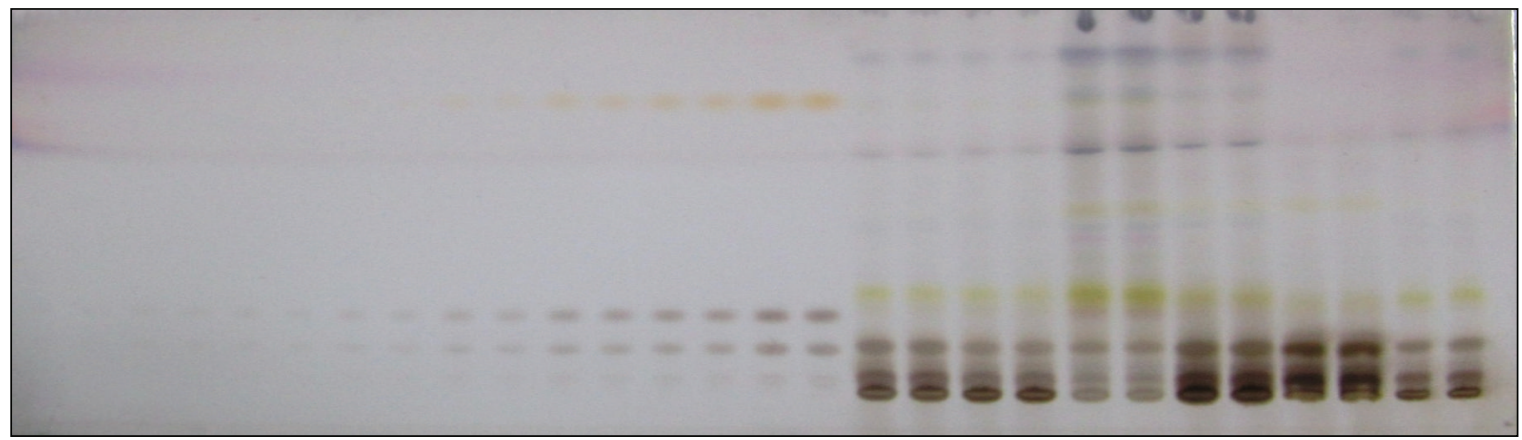

(a)

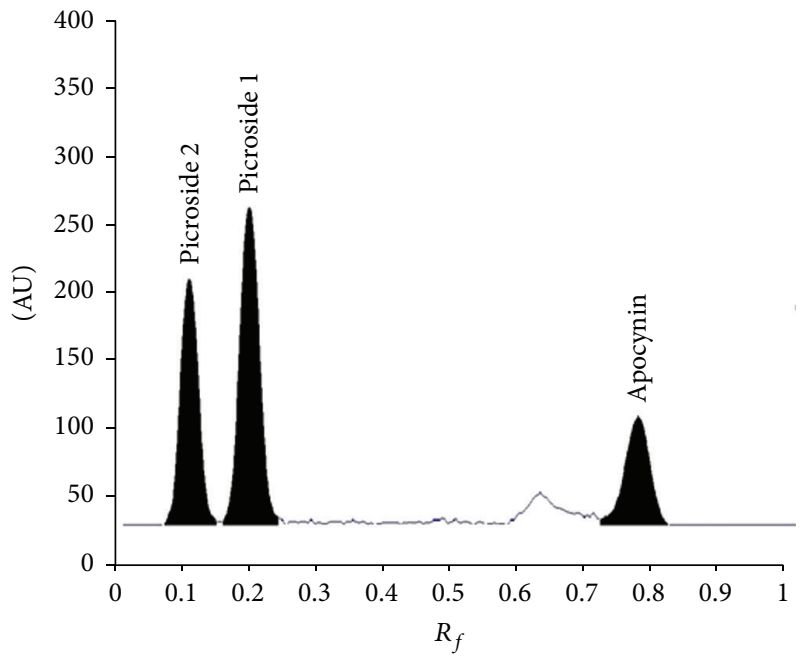

(b)

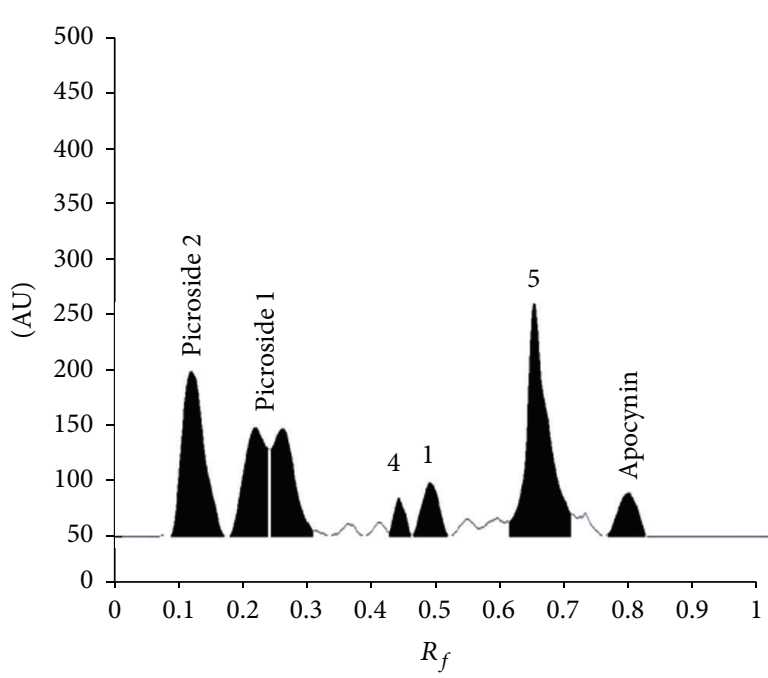

(c)

Figure 8: Developed HPTLC plate at $500 \mathrm{~nm}$ showing spots of picrosides 1 and 2 and apocynin at different concentrations. Standard and in sample (a), HPTLC chromatograms of standard picrosides 1 and 2 and apocynin (b), and sample (c).

frequently occurring and rare cells correlating to basophils, monocytes, eosinophils, etc.) were determined using a blood automatic analyzer.

2.19. Statistical Analysis. Values were expressed as mean \pm standard deviation (SD). One-way analysis of variance (ANOVA) followed by Dunnett's test (Graph Pad, San Diego, $\mathrm{CA}$ ) was used for statistical analysis. All the treatment groups were compared with the toxic control group. $P$ values $<0.05$ were considered as statistically significant.

\section{Results and Discussion}

The plant material was extracted using crude alcohol (70\%) by maceration and Reflux extraction after optimization. The hot extraction was selected for study due to its high yields and called mother extract $(25.6 \% \mathrm{w} / \mathrm{w})$. This was further fractionated using hexane $(9 \% \mathrm{w} / \mathrm{w})$, DCM $(31 \% \mathrm{w} / \mathrm{w}), \mathrm{n}-$ butanol $(23 \% \mathrm{w} / \mathrm{w})$, acetone $(11 \% \mathrm{w} / \mathrm{w})$, methanol $(16 \% \mathrm{w} / \mathrm{w})$, and water $(7 \% \mathrm{w} / \mathrm{w})$. However, $5.2 \mathrm{~g}$ of mother extract $(4 \% \mathrm{w} / \mathrm{w})$ of the drug was lost during the processing (Figure 1).
3.1. Cytotoxicity Assay. The cytotoxicity of hydroalcoholic (mother) extract and its fractions of P. kurroa on selected cancer cell lines was determined by MTT assay at 24, 48, and $72 \mathrm{~h}$, which showed the best activity at $72 \mathrm{~h}$. The results of cytotoxicity assay showed that hexane and water fractions did not produce any substantial cytotoxicity and were found safe in the tested concentration $\left(500 \mu \mathrm{g} \mathrm{mL}^{-1}\right)$ in all cell lines. However, mother extract, DCM, n-butanol, acetone, and methanol fractions produced good cytotoxicity varying between 36 and $270 \mu \mathrm{g} \mathrm{mL}^{-1}$ at $72 \mathrm{~h}$ among different cell lines (Figure 2). The DCM fraction $\left(\mathrm{IC}_{50}\right.$ ranging from 36 to $51 \mu \mathrm{g} \mathrm{mL}^{-1}$ at $72 \mathrm{~h}$ ) showed best cytotoxic activities towards all cancer cell lines (Figures 3 and 4(a)-4(d)). The best cytotoxic activity of DCM fraction from P. kurroa may be attributed to the presence or synergistic activities of phytochemical components including sterol, triterpenes, and polyphenols [18, 20, 22-34]. However, betulinic acid may be attributed to this activity [41], since DCM fraction is rich in it, as proved by our analytical studies. MTT assay results of all the four cell lines proved that cytotoxicity was highest in DCM, followed by n-butanol, methanol fraction, and mother extract at $72 \mathrm{~h}$ (Figures 4(a)-4(d)). As the DCM fraction of hydroalcoholic extract of $P$. kurroa exhibited the 


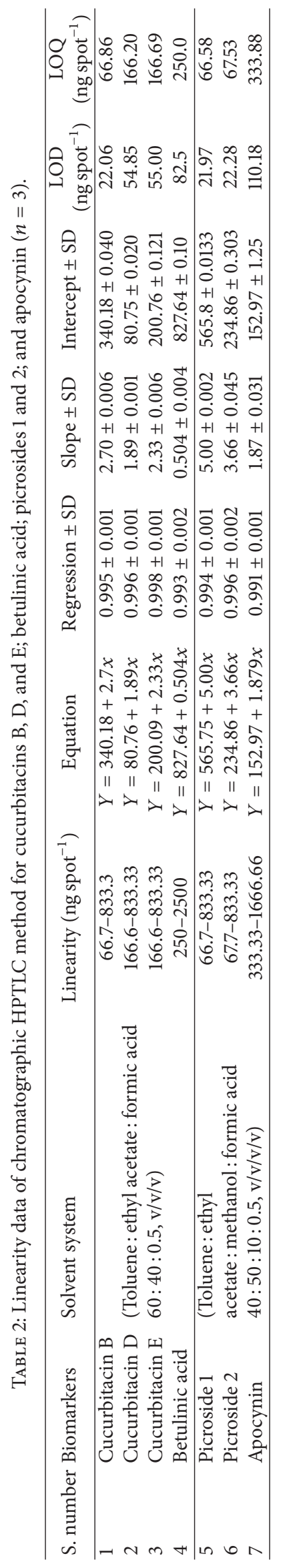


Table 3: Precision of the method for the estimation of cucurbitacins B, D, and E; betulinic acid; picrosides 1 and 2; and apocynin ( $n=6)$.

\begin{tabular}{|c|c|c|c|c|c|c|}
\hline \multirow{2}{*}{$\begin{array}{l}\text { Conc. } \\
\left(\text { ng }^{\mathrm{a}} \operatorname{spot}^{-1}\right) \\
\end{array}$} & \multicolumn{2}{|c|}{ Interday precision } & \multicolumn{2}{|c|}{ Intraday precision } & \multicolumn{2}{|c|}{ Interanalyst precision } \\
\hline & Mean peak area $\pm \mathrm{SD}^{\mathrm{b}}$ & $\% \mathrm{RSD}^{\mathrm{c}}$ & Mean peak area \pm SD & $\% \mathrm{RSD}$ & Mean peak area \pm SD & $\% \mathrm{RSD}$ \\
\hline \multicolumn{7}{|c|}{ Cucurbitacin B } \\
\hline 100 & $541.00 \pm 10.53$ & 1.94 & $552.0 \pm 10.81$ & 1.95 & $541.0 \pm 11.00$ & 2.03 \\
\hline 200 & $860.66 \pm 15.04$ & 1.74 & $875.0 \pm 16.50$ & 1.88 & $859.66 \pm 16.62$ & 1.93 \\
\hline 400 & $1585.0 \pm 26.72$ & 1.68 & $1594.66 \pm 25.71$ & 1.61 & $1580.66 \pm 29.36$ & 1.85 \\
\hline \multicolumn{7}{|c|}{ Cucurbitacin D } \\
\hline 200 & $461.33 \pm 10.01$ & 2.17 & $470.00 \pm 10.00$ & 2.12 & $442.66 \pm 8.73$ & 1.97 \\
\hline 400 & $825.00 \pm 15.52$ & 1.88 & $837.33 \pm 15.94$ & 1.90 & $838.33 \pm 16.04$ & 1.91 \\
\hline 800 & $1634.33 \pm 32.12$ & 1.96 & $1647.33 \pm 33.29$ & 2.02 & $1652.06 \pm 34.59$ & 2.09 \\
\hline \multicolumn{7}{|c|}{ Cucurbitacin E } \\
\hline 200 & $637.33 \pm 13.01$ & 2.04 & $641.0 \pm 12.66$ & 1.97 & $632.66 \pm 12.85$ & 2.03 \\
\hline 400 & $1157.33 \pm 19.75$ & 1.70 & $1172.66 \pm 20.40$ & 1.73 & $1162.66 \pm 21.54$ & 1.85 \\
\hline 800 & $2138.0 \pm 42.22$ & 1.97 & $2135.66 \pm 46.36$ & 2.17 & $2135.33 \pm 40.07$ & 1.87 \\
\hline \multicolumn{7}{|c|}{ Betulinic acid } \\
\hline 250 & $979.66 \pm 18.50$ & 1.88 & $976 \pm 20.59$ & 2.10 & $981.33 \pm 19.55$ & 1.99 \\
\hline 500 & $1039.66 \pm 21.00$ & 2.02 & $1022.66 \pm 19.55$ & 1.91 & $1031.33 \pm 20.03$ & 1.94 \\
\hline 1000 & $1374 \pm 25.89$ & 1.88 & $1375.66 \pm 25.53$ & 1.85 & $1387.33 \pm 26.63$ & 1.91 \\
\hline \multicolumn{7}{|c|}{ Picroside 1} \\
\hline 100 & $941.00 \pm 17.50$ & 1.84 & $944.0 \pm 19.50$ & 2.05 & $943.0 \pm 17.08$ & 1.81 \\
\hline 200 & $1642.66 \pm 33.5$ & 2.04 & $1639.33 \pm 30.92$ & 1.88 & $1644.33 \pm 32.86$ & 1.99 \\
\hline 400 & $2936.0 \pm 56.95$ & 1.93 & $2940.0 \pm 56.66$ & 1.92 & $2929.33 \pm 59.65$ & 2.03 \\
\hline \multicolumn{7}{|c|}{ Picroside 2} \\
\hline 100 & $502.0 \pm 9.53$ & 1.90 & $504.66 \pm 10.50$ & 2.08 & $506.0 \pm 9.16$ & 1.81 \\
\hline 200 & $1005.66 \pm 18.0$ & 1.84 & $1008.33 \pm 18.94$ & 1.82 & $1007.33 \pm 20.10$ & 1.99 \\
\hline 400 & $1916.66 \pm 33.08$ & 1.72 & $1919.33 \pm 37.01$ & 1.92 & $1922.66 \pm 40.69$ & 2.11 \\
\hline \multicolumn{7}{|c|}{ Apocynin } \\
\hline 400 & $795.0 \pm 15.01$ & 1.88 & $799.0 \pm 15.52$ & 1.94 & $803.00 \pm 15.09$ & 1.88 \\
\hline 800 & $1583.33 \pm 31.0$ & 1.95 & $1589.33 \pm 32.25$ & 2.02 & $1594.33 \pm 31.65$ & 1.98 \\
\hline 1000 & $2225.66 \pm 45.93$ & 2.05 & $2231.33 \pm 41.63$ & 1.86 & $2227.33 \pm 40.50$ & 1.81 \\
\hline
\end{tabular}

${ }^{\mathrm{a}}$ Nanogram. ${ }^{\mathrm{b}}$ Standard deviation. ${ }^{\mathrm{c}}$ Relative standard deviation.

highest cytotoxicity towards the tested cell lines, and this may be due to vacuole formation, membrane blebbing, nuclear condensation, and detachment of cells from the substratum and shrinkage of cells as well as development of apoptotic bodies [42, 43].

3.2. HPTLC Analysis. The HPTLC fingerprinting of mother extract and different fractions was developed on silica gel. DCM fraction showed the maximum number of UV active compounds and was thus detected at $254 \mathrm{~nm}$, whereas other fractions and mother extract were detected at $520 \mathrm{~nm}$ after visualization, using anisaldehyde sulphuric acid reagents (Figures 5(a)-5(f); Table 1). Table 1 showed different solvent systems used for fingerprinting of extract/fractions with number of spots present in them and their respective $R_{f}$ values. The maximum number of compounds was observed in hexane and butanol fraction; however DCM fraction showed the presence of $8 \mathrm{UV}$ active compounds.
3.3. Simultaneous Estimation of Cucurbitacins B, D, and E, Betulinic Acid, Picrosides 1 and 2, and Apocynin, Using Validated HPTLC Methods. The mobile phase toluene: ethyl acetate: formic acid $(60: 40: 0.5, \mathrm{v} / \mathrm{v} / \mathrm{v})$ was optimized for simultaneous estimation of cucurbitacins B, D, and E, which showed good separation of all three compounds with compact peaks at different $R_{f}$ values $(0.53 \pm 0.01$, $0.16 \pm 0.02$, and $0.43 \pm 0.01$, resp.) (Figures $6(\mathrm{a})-6(\mathrm{c})$ ) on scanning at $240 \mathrm{~nm}$ without derivatization. Betulinic acid was well separated, using the same solvent as indicated above for cucurbitacins, but visualized after derivatization using anisaldehyde sulphuric acid. It was scanned at $595 \mathrm{~nm}$ wavelength, which showed compact spot and sharp peak at $R_{f} 0.76 \pm 0.01$ (Figures $7(\mathrm{a})-7(\mathrm{c})$ ). The toluene: ethyl acetate: methanol: formic acid $(40: 50: 10: 0.2, \mathrm{v} / \mathrm{v} / \mathrm{v} / \mathrm{v})$ was optimized for separation and quantification of picrosides 1 and 2 and apocynin, which gave a good separation among components. The plate was scanned at $500 \mathrm{~nm}$ wavelengths after derivatization with anisaldehyde sulphuric acid, which 
TABLE 4: (a) Robustness of the HPTLC method for estimation of cucurbitacins B, D, and E; betulinic acid; picrosides 1 and 2; and apocynin by changing detecting of wavelengths. (b) Robustness of the HPTLC method for estimation of cucurbitacins B, D, and E and betulinic acid by changing detecting of mobile phase composition. (c) Robustness of the HPTLC method for estimation of picrosides 1 and 2 and apocynin by changing detecting of mobile phase composition.

(a)

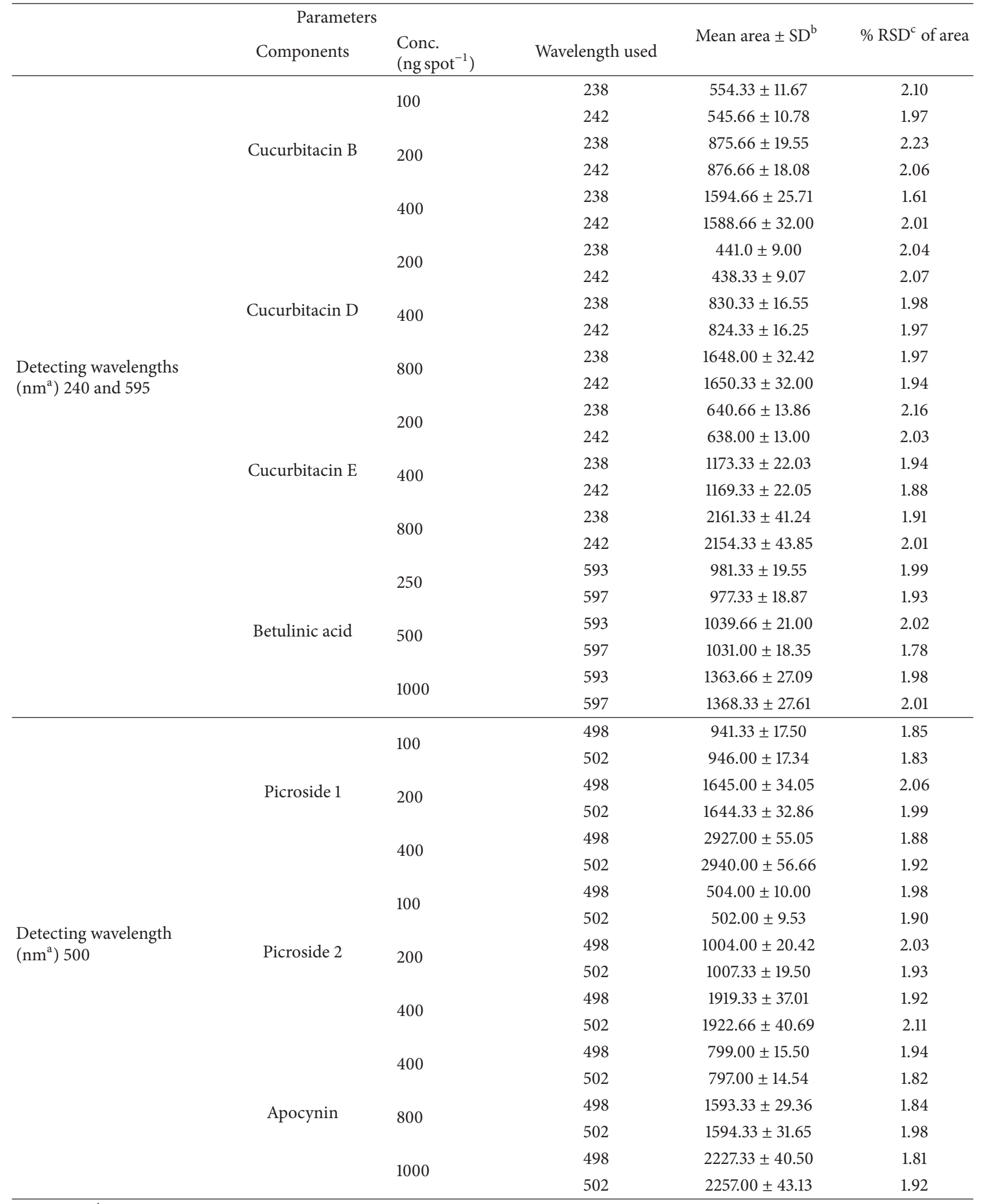

\footnotetext{
${ }^{\mathrm{a}}$ Nanometer. ${ }^{\mathrm{b}}$ Standard deviation. ${ }^{\mathrm{c}}$ Relative standard deviation.
} 
(b)

\begin{tabular}{|c|c|c|c|c|}
\hline \multirow[b]{2}{*}{ Components } & \multicolumn{2}{|c|}{ Parameters } & \multirow[b]{2}{*}{ Mean area $\pm \mathrm{SD}^{\mathrm{a}}$} & \multirow[b]{2}{*}{$\% \mathrm{RSD}^{\mathrm{b}}$ of area } \\
\hline & $\begin{array}{l}\text { Conc. } \\
\left(\text { ng spot }^{-1}\right)\end{array}$ & $\begin{array}{l}\text { Mobile phase composition } \\
\text { (toluene : ethyl acetate }: \text { formic acid, } \\
60: 40: 0.5, \mathrm{v} / \mathrm{v} / \mathrm{v} \text { ) }\end{array}$ & & \\
\hline \multirow{9}{*}{ Cucurbitacin B } & \multirow{3}{*}{100} & $63: 37: 0.5$ & $545.0 \pm 11.78$ & 2.16 \\
\hline & & $61: 39: 0.5$ & $552.0 \pm 12.00$ & 2.17 \\
\hline & & $57: 43: 0.5$ & $544.0 \pm 10.44$ & 1.91 \\
\hline & \multirow{3}{*}{200} & $63: 37: 0.5$ & $872.33 \pm 16.28$ & 1.86 \\
\hline & & $61: 39: 0.5$ & $868.33 \pm 16.25$ & 1.87 \\
\hline & & $57: 43: 0.5$ & $873.33 \pm 16.56$ & 1.91 \\
\hline & \multirow{3}{*}{400} & $63: 37: 0.5$ & $1605.0 \pm 28.16$ & 1.75 \\
\hline & & $61: 39: 0.5$ & $1590.33 \pm 26.33$ & 1.67 \\
\hline & & $57: 43: 0.5$ & $1603.66 \pm 30.66$ & 1.91 \\
\hline \multirow{9}{*}{ Cucurbitacin D } & \multirow{3}{*}{200} & $63: 37: 0.5$ & $437.0 \pm 9.00$ & 2.06 \\
\hline & & $61: 39: 0.5$ & $440.67 \pm 9.5$ & 2.16 \\
\hline & & $57: 43: 0.5$ & $442.33 \pm 10.07$ & 2.28 \\
\hline & \multirow{3}{*}{400} & $63: 37: 0.5$ & $826.33 \pm 15.04$ & 1.82 \\
\hline & & $61: 39: 0.5$ & $828.33 \pm 17.01$ & 2.05 \\
\hline & & $57: 43: 0.5$ & $831.33 \pm 15.72$ & 1.89 \\
\hline & \multirow{3}{*}{800} & $63: 37: 0.5$ & $1644.00 \pm 36.05$ & 2.28 \\
\hline & & $61: 39: 0.5$ & $1647.00 \pm 29.82$ & 1.81 \\
\hline & & $57: 43: 0.5$ & $1643.66 \pm 38.22$ & 2.33 \\
\hline \multirow{9}{*}{ Cucurbitacin E } & \multirow{3}{*}{200} & $63: 37: 0.5$ & $641.33 \pm 12.34$ & 1.92 \\
\hline & & $61: 39: 0.5$ & $645.33 \pm 12.01$ & 1.86 \\
\hline & & $57: 43: 0.5$ & $638.00 \pm 12.53$ & 1.96 \\
\hline & \multirow{3}{*}{400} & $63: 37: 0.5$ & $1176.67 \pm 23.71$ & 2.02 \\
\hline & & $61: 39: 0.5$ & $1172.33 \pm 22.59$ & 1.93 \\
\hline & & $57: 43: 0.5$ & $1170.33 \pm 23.24$ & 1.98 \\
\hline & \multirow{3}{*}{800} & $63: 37: 0.5$ & $2149.67 \pm 40.55$ & 1.89 \\
\hline & & $61: 39: 0.5$ & $2154.0 \pm 43.51$ & 2.02 \\
\hline & & $57: 43: 0.5$ & $2156.33 \pm 44.0$ & 2.04 \\
\hline \multirow{9}{*}{ Betulinic acid } & \multirow{3}{*}{250} & $63: 37: 0.5$ & $978.0 \pm 17.78$ & 1.81 \\
\hline & & $61: 39: 0.5$ & $977.33 \pm 18.87$ & 1.93 \\
\hline & & $57: 43: 0.5$ & $972.33 \pm 19.85$ & 2.04 \\
\hline & \multirow{3}{*}{500} & $63: 37: 0.5$ & $1033.00 \pm 21.79$ & 2.10 \\
\hline & & $61: 39: 0.5$ & $1022.66 \pm 17.50$ & 1.71 \\
\hline & & $57: 43: 0.5$ & $1037.33 \pm 18.92$ & 1.82 \\
\hline & \multirow{3}{*}{1000} & $63: 37: 0.5$ & $1364.66 \pm 25.69$ & 1.88 \\
\hline & & $61: 39: 0.5$ & $1371.00 \pm 26.05$ & 1.90 \\
\hline & & $57: 43: 0.5$ & $1363.66 \pm 27.09$ & 1.98 \\
\hline
\end{tabular}

${ }^{\mathrm{a}}$ Standard deviation. ${ }^{\mathrm{b}}$ Relative standard deviation.

(c)

\begin{tabular}{|c|c|c|c|c|}
\hline \multirow[b]{2}{*}{ Components } & \multicolumn{2}{|c|}{ Parameters } & \multirow[b]{2}{*}{ Mean area $\pm \mathrm{SD}^{\mathrm{a}}$} & \multirow[b]{2}{*}{$\% \mathrm{RSD}^{\mathrm{b}}$ of area } \\
\hline & $\begin{array}{l}\text { Conc. } \\
\left(\text { ng spot }^{-1}\right)\end{array}$ & $\begin{array}{c}\text { Mobile phase composition } \\
\text { (toluene : ethyl } \\
\text { acetate : methanol : formic acid, } \\
40: 50: 10: 0.5, \mathrm{v} / \mathrm{v} / \mathrm{v} / \mathrm{v})\end{array}$ & & \\
\hline \multirow{9}{*}{ Picroside 1} & \multirow{3}{*}{100} & $42: 48: 10: 0.2$ & $946.00 \pm 17.34$ & 1.83 \\
\hline & & $38: 52: 10: 0.2$ & $948.33 \pm 17.50$ & 1.84 \\
\hline & & $40: 52: 08: 0.2$ & $948.66 \pm 18.00$ & 1.89 \\
\hline & \multirow{3}{*}{200} & $42: 48: 10: 0.2$ & $1645.00 \pm 34.04$ & 2.06 \\
\hline & & $38: 52: 10: 0.2$ & $1643.00 \pm 31.43$ & 1.91 \\
\hline & & $40: 52: 08: 0.2$ & $1643.66 \pm 30.66$ & 1.86 \\
\hline & \multirow{3}{*}{400} & $42: 48: 10: 0.2$ & $2927.00 \pm 55.05$ & 1.88 \\
\hline & & $38: 52: 10: 0.2$ & $2931.66 \pm 60.87$ & 2.07 \\
\hline & & $40: 52: 08: 0.2$ & $2927.66 \pm 60.17$ & 2.05 \\
\hline
\end{tabular}


(c) Continued.

\begin{tabular}{|c|c|c|c|c|}
\hline \multicolumn{5}{|c|}{ Parameters } \\
\hline Components & $\begin{array}{l}\text { Conc. } \\
\left(\text { ng spot }^{-1}\right)\end{array}$ & $\begin{array}{l}\text { Mobile phase composition } \\
\text { (toluene : ethyl } \\
\text { acetate : methanol : formic acid, } \\
40: 50: 10: 0.5, \mathrm{v} / \mathrm{v} / \mathrm{v} / \mathrm{v} \text { ) }\end{array}$ & Mean area $\pm \mathrm{SD}^{\mathrm{a}}$ & $\% \mathrm{RSD}^{\mathrm{b}}$ of area \\
\hline \multirow{9}{*}{ Picroside 2} & \multirow{3}{*}{100} & $42: 48: 10: 0.2$ & $504.00 \pm 10.00$ & 1.98 \\
\hline & & $38: 52: 10: 0.2$ & $501.33 \pm 9.81$ & 1.95 \\
\hline & & $40: 52: 08: 0.2$ & $506.66 \pm 9.71$ & 1.91 \\
\hline & \multirow{3}{*}{200} & $42: 48: 10: 0.2$ & $1007.33 \pm 19.50$ & 1.93 \\
\hline & & $38: 52: 10: 0.2$ & $1005.66 \pm 19.85$ & 1.97 \\
\hline & & $40: 52: 08: 0.2$ & $1004.00 \pm 20.42$ & 2.03 \\
\hline & \multirow{3}{*}{400} & $42: 48: 10: 0.2$ & $1914.33 \pm 33.50$ & 1.75 \\
\hline & & $38: 52: 10: 0.2$ & $1922.66 \pm 40.68$ & 2.11 \\
\hline & & $40: 52: 08: 0.2$ & $1915.33 \pm 37.68$ & 1.96 \\
\hline \multirow{9}{*}{ Apocynin } & \multirow{3}{*}{400} & $42: 48: 10: 0.2$ & $800.66 \pm 15.94$ & 1.99 \\
\hline & & $38: 52: 10: 0.2$ & $801.66 \pm 15.63$ & 1.94 \\
\hline & & $40: 52: 08: 0.2$ & $797.00 \pm 14.52$ & 1.82 \\
\hline & \multirow{3}{*}{800} & $42: 48: 10: 0.2$ & $1593.33 \pm 29.36$ & 1.84 \\
\hline & & $38: 52: 10: 0.2$ & $1587.66 \pm 28.67$ & 1.80 \\
\hline & & $40: 52: 08: 0.2$ & $1597.00 \pm 30.61$ & 1.91 \\
\hline & \multirow{3}{*}{1000} & $42: 48: 10: 0.2$ & $2222.66 \pm 42.44$ & 1.90 \\
\hline & & $38: 52: 10: 0.2$ & $2257.00 \pm 43.13$ & 1.91 \\
\hline & & $40: 52: 08: 0.2$ & $2228.00 \pm 44.22$ & 1.98 \\
\hline
\end{tabular}

${ }^{\mathrm{a}}$ Standard deviation. ${ }^{\mathrm{b}}$ Relative standard deviation.

produce very well defined peaks of picrosides 1 and 2 and apocynin at $R_{f}$ values $0.23 \pm 0.01,0.11 \pm 0.02$, and $0.77 \pm 0.01$, respectively (Figures $8(\mathrm{a})-8(\mathrm{c})$ ).

\subsection{Validation of the Method Developed}

3.4.1. Calibration Curve and Linearity. The newly developed methods for simultaneous estimation of cucurbitacins $B$, $\mathrm{D}$, and E; betulinic acid; picrosides 1 and 2; and apocynin were found linear for a wide range of concentration with good regression coefficient $(>0.99)$. The linearity data of all the biomarkers developed such as range linearity, regression equation, regression coefficient, slope, intercept, LOD, and LOQ are given in Table 2.

3.4.2. Precision. The method precision and intermediate precisions were determined and reported in terms of \% RSD. Precision of the proposed method was obtained by repeatability and intermediate precision at three different concentration levels. The \% RSD of interday precision, intraday precision, and interanalyst precision was within the range of 1.61-2.12 for all compounds, as reported in Table 3.

3.4.3. Robustness of the Method. The low values of \% RSD obtained after introducing small but deliberate changes in mobile phase composition and wavelength indicated robustness of the methods (Tables $4(\mathrm{a})-4(\mathrm{c})$ ) at 3 different concentration levels.
3.4.4. Specificity. The specificity of the methods was ascertained by analysing standard drugs and samples. The detection of spot for cucurbitacins B, D, and E; betulinic acid; picrosides 1 and 2; and apocynin in DCM sample was confirmed by equating $R_{f}$ and spectra of spot with the standard. The peak purity was estimated by comparing the spectra at three different levels, that is, at peak start, peak apex, and peak end positions of the spot.

3.4.5. Limit of Detection (LOD) and Limit of Quantification (LOQ). The LOD and LOQ of different markers were calculated as per the standard protocol $[36,37]$ and reported in Table 3. The LOD of markers lies in the range of 21.94$133.0 \mathrm{ng}$, indicating good sensitivity of methods for simultaneous quantification of compounds.

3.4.6. Accuracy as Recovery. The accuracy was calculated as recovery by standard addition method by spiking $0,50,100$, and $150 \%$ of analyte in preanalyzed samples, showing good recovery of all biomarkers used and lying in the range of 99101.4\% (Table 5).

3.4.7. Estimation of Cucurbitacins B, D, and E; Betulinic Acid; Picrosides 1 and 2; and Apocynin in DCM Fraction. The newly developed and validated HPTLC method was applied for the analysis of cucurbitacins B, D, and E; betulinic acid; picrosides 1 and 2; and apocynin in DCM fraction of $P$. kurroa 


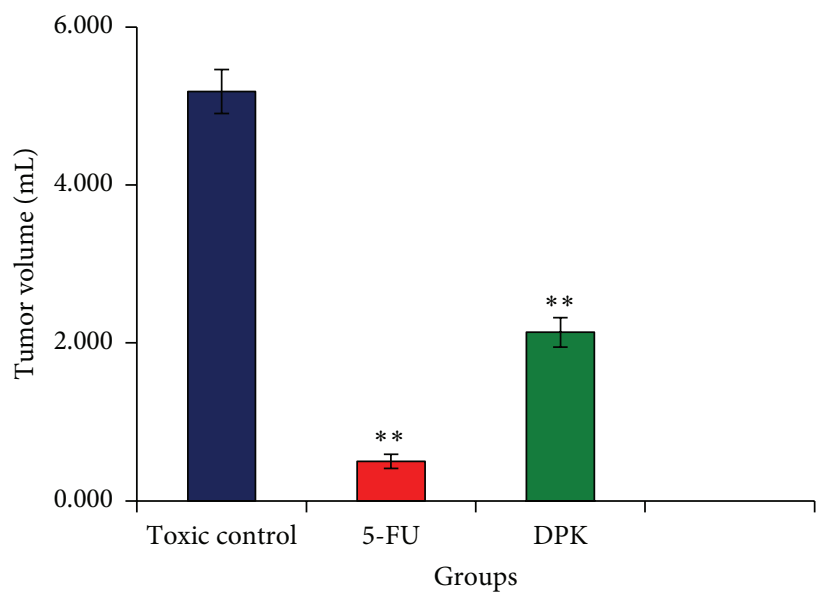

(a)

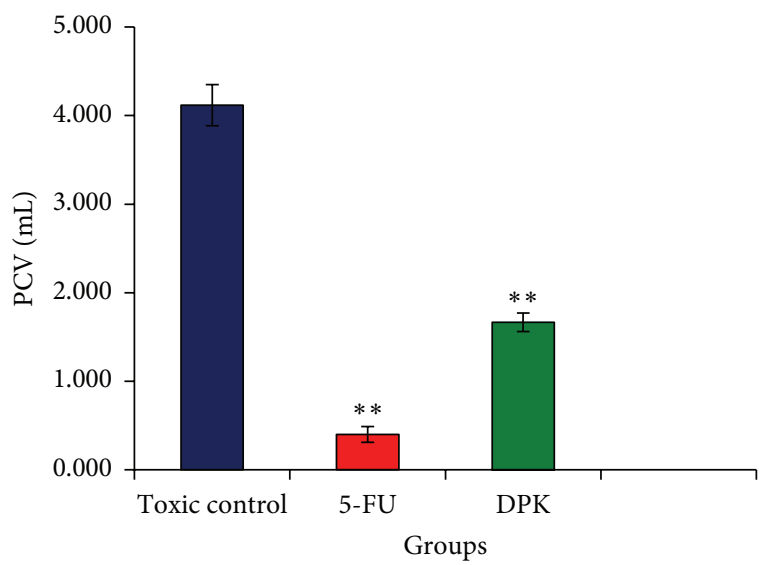

(c)

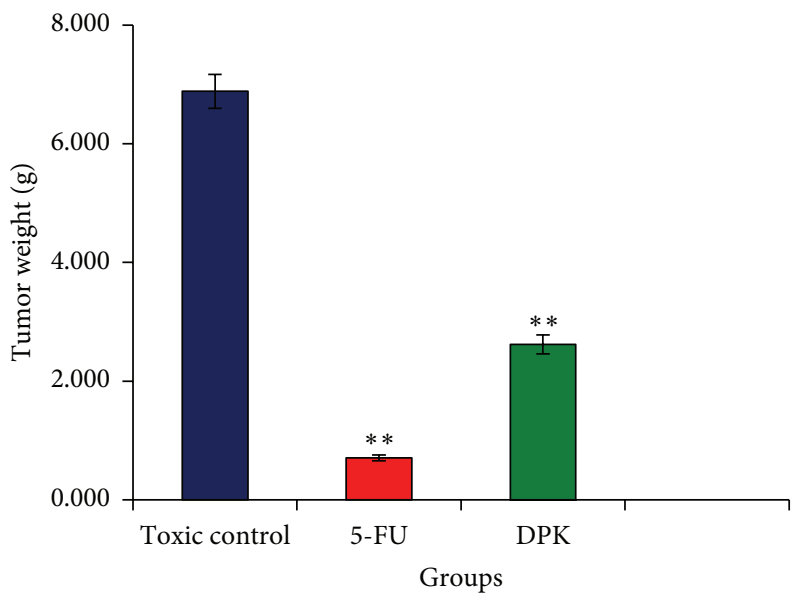

(b)

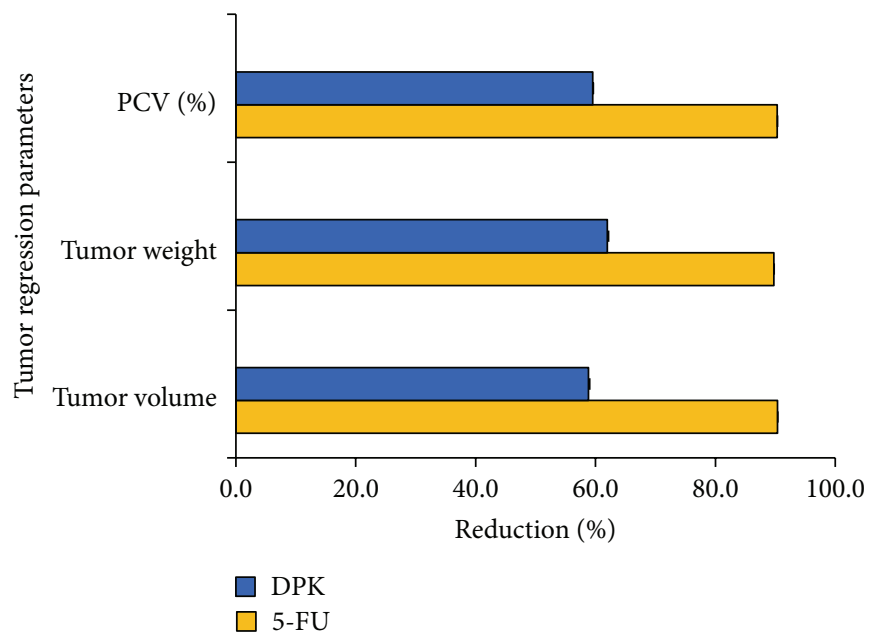

(d)

Figure 9: Showing tumor regression parameters as obtained on Balb/c mice after ten days of oral administration of DCM fraction of hydroalcoholic extract of $P$. kurroa ( $* *$ showed $p<0.01$ followed by Dunnett's test in comparison to EAC control).

rhizome. The peak areas of triplicate samples were analyzed by regression equation obtained from the calibration plot. The content obtained for different markers is reported in Table 6. Cucurbitacin D was found absent in DCM fraction (BAF) of P. kurroa.

3.5. In Vivo Anticancer Activity of DCM Fraction. DCM fraction of $P$. kurroa showed a significant effect on tumor regression parameters of EAC cell bearing mice. The DCM fraction significantly $(P<0.01)$ reduced the tumor volume, tumor weight, and \% packed cell volume at a dose of $50 \mathrm{mg} \mathrm{Kg}^{-1}$ body weight, as compared with EAC (toxic) control group (Figure 9). The results were almost comparable to that of 5-FU, a standard marketed drug. There was a significant decrease in number of tumor cells on treatment with DCM fraction and 5-FU in tumor-bearing mice, as compared with EAC control. Similarly, a percentage of viable cells were decreased significantly in treatment groups, as compared with untreated EAC control (Table 7).
Haematological parameters of EAC tumor-bearing and treatment group mice were studied on day 14, which showed significant changes in the number of WBCs only, and that was reversed in treated groups as compared with untreated EAC control. Other parameters such as haemoglobin, RBC, lymphocytes, hematocrit (HCT), RDW, and PLT were found to be near normal and did not produce any significant alteration (Table 8).

The well-founded criteria for assessing the value of any anticancer drug are the increase in life span, the loss of leukemic cells from the blood, and reduction of solid tumor volume. Transplantable tumor cells, such as EAC, are rapidly growing cancer cells with aggressive behavior [37-39]. The tumor implantation includes a local inflammatory reaction by increasing vascular permeability and results in an intense ascetic fluid accumulation [37, 39]. Our results showed significant reversal of tumor regression parameters accompanied by a reduction in WBC count after treatment with DCM fraction of hydroalcoholic extract of $P$. kurroa. The best active/enriched fraction also inhibited the accumulation of 
TABLE 5: Accuracy of the HPTLC methods for the estimation of cucurbitacins B and E, betulinic acid, picrosides 1 and 2, and apocynin.

\begin{tabular}{lcccc}
\hline $\begin{array}{l}\text { \% of standard } \\
\text { spiked to the } \\
\text { sample }\end{array}$ & $\begin{array}{c}\text { Theoretical } \\
\text { content } \\
\left(\mu \mathrm{gL}^{-1}\right)\end{array}$ & $\begin{array}{c}\text { Amount of } \\
\text { drug } \\
\text { recovered } \\
\left(\mu \mathrm{gL}^{-1}\right)\end{array}$ & $\begin{array}{c}\text { \% of drug } \\
\text { recovered }\end{array}$ & \% RSD \\
\hline
\end{tabular}

Cucurbitacin B

$\begin{array}{lllll}0 & 300 & 299.66 & 99.88 & 0.51 \\ 50 & 450 & 450.66 & 100.14 & 0.34 \\ 100 & 600 & 600.67 & 100.11 & 0.25 \\ 150 & 750 & 751.33 & 100.17 & 0.07\end{array}$

Cucurbitacin E

100

150

Cucurbitacin D

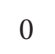

50

100

150

Betulinic acid

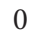

50

100

150

Picroside 1

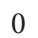

50

100

150

Picroside 2

\begin{tabular}{lcccc}
0 & 130 & 131.66 & 101.28 & 0.43 \\
50 & 195 & 196.00 & 100.51 & 0.52 \\
100 & 260 & 261.66 & 100.64 & 0.22 \\
150 & 325 & 324.66 & 99.89 & 0.17 \\
Apocynin & & & & \\
0 & 50 & 49.33 & 98.66 & 1.17 \\
50 & 75 & 74.33 & 99.11 & 0.77 \\
100 & 100 & 99.0 & 99.00 & 1.01 \\
150 & 125 & 124.66 & 99.73 & 0.46 \\
\hline
\end{tabular}

ascetic fluid in the peritoneal cavity of the tumor-bearing animals. These results clearly demonstrated the antitumor effect of $P$. kurroa on EAC tumor cells.
TABLE 6: Estimation of cucurbitacins $B$ and E, betulinic acid, picrosides 1 and 2, and apocynin in DCM fraction of P. kurroa.

\begin{tabular}{lc}
\hline Components & $\begin{array}{c}\text { \% yield from DCM fraction } \\
\text { of P. kurroa \%w/w }\end{array}$ \\
\hline Cucurbitacin B & $2.98 \pm 0.051$ \\
Cucurbitacin E & $0.707 \pm 0.004$ \\
Cucurbitacin D & Nil \\
Betulinic acid & $3.43 \pm 0.351$ \\
Picroside 1 & $0.537 \pm 0.030$ \\
Picroside 2 & $1.33 \pm 0.036$ \\
Apocynin & $0.526 \pm 0.004$ \\
\hline
\end{tabular}

\section{Conclusion}

This study has indicated that hydroalcoholic (mother) extract and its medium polar fractions of $P$. kurroa exhibited cytotoxic potential, while water and hexane fractions did not produce cytotoxicity in cervical and breast cancer cell lines up to $500 \mu \mathrm{g} \mathrm{mL}^{-1}$ and $72 \mathrm{~h}$. The DCM fraction was found as best active fraction in in vitro testing with lowest $\mathrm{IC}_{50}$ value (36$51 \mu \mathrm{g} \mathrm{mL}^{-1}$ at $72 \mathrm{~h}$ ) among the four tested cell lines. This might be due to the presence of cucurbitacins $\mathrm{B}$ and $\mathrm{E}$; betulinic acid; picrosides 1 and 2; and apocynin, as obtained from analytical studies and supported by earlier reports $[15,18-$ 21]. The analysis of seven markers (six terpenoid and one flavonoid) for quality control of DCM fraction using simultaneous HPTLC methods in present investigation is unique and being reported for the first time. The oral administration of DCM fraction (BAF) of hydroalcoholic (mother) extract of P. kurroa $\left(50 \mathrm{mg} \mathrm{Kg}^{-1}\right)$ in Balb/c mice reduced the tumor volume and weight and \% packed cell volume as well as WBC reflecting antitumor activity of $P$. kurroa. Our results suggest that DCM fraction of hydroalcoholic extract of $P$. kurroa might be a good candidate for development as anticancer drug and may come out as a new future phytopharmaceutical drug since inclusion of phytopharmaceuticals/enriched fractions is already in the process in several pharmacopoeias. In addition, simultaneous methods developed and validated for quantification of cucurbitacin (B, D, and E), betulinic acid, picroside 1, picroside 2, and apocynin can be used for its quality control as well as for that of other drugs containing them as ingredient.

\section{Conflict of Interests}

The authors declare that there is no conflict of interests regarding the publication of this paper.

\section{Authors' Contribution}

Sayeed Ahmad and Syed Akhtar Husain made equal contribution. 
TABLE 7: Tumor cell count of groups (groups II, III, and IV) (mean \pm SD, $n=3$ ).

\begin{tabular}{|c|c|c|c|c|c|}
\hline Groups & $\begin{array}{c}\text { Total cells } / \mathrm{mL} * 10^{7} \pm \\
\mathrm{SD}\end{array}$ & $\begin{array}{c}\text { Viable cells } / \mathrm{mL} * \\
10^{7} \pm \mathrm{SD}\end{array}$ & $\begin{array}{c}\text { Nonviable cells } / \mathrm{mL} * \\
10^{7} \pm \mathrm{SD} \\
\end{array}$ & $\begin{array}{c}\% \text { viable cells } \pm \\
\text { SD }\end{array}$ & $\begin{array}{c}\% \text { nonviable cells } \pm \\
\text { SD }\end{array}$ \\
\hline EAC & $9.93 \pm 0.81$ & $9.43 \pm 0.57$ & $0.50 \pm 0.59$ & 95.22 & 4.77 \\
\hline 5-FU & $2.91 \pm 0.33^{* *}$ & $0.53 \pm 0.17^{* *}$ & $2.38 \pm 0.31^{* *}$ & $18.28^{* *}$ & $81.71^{* *}$ \\
\hline DPK & $4.96 \pm 0.54^{* *}$ & $2.31 \pm 0.43^{* *}$ & $2.65 \pm 0.74^{* *}$ & $47.23^{* *}$ & $52.76^{* *}$ \\
\hline
\end{tabular}

EAC: Ehrlich ascites carcinoma, 5-FU: 5-fluorouracil, DPK: dichloromethane fraction of $P$. kurroa $(* *$ showed $P<0.01$ followed by Dunnett's test in comparison to EAC control).

TABLE 8: Comparative haematological profile of EAC, control, standard, and DCM fraction treated groups of Balb/C mice after ten days of treatment.

\begin{tabular}{|c|c|c|c|c|}
\hline Parameters & Control \pm SD & EAC control \pm SD & $5-\mathrm{FU} \pm \mathrm{SD}$ & $\mathrm{DPK} \pm \mathrm{SD}$ \\
\hline $\mathrm{WBC} * 10^{3} / \mu \mathrm{L}$ & $5.20 \pm 0.26$ & $9.50 \pm 0.47$ & $3.10 \pm 0.15^{* *}$ & $0.55 \pm 0.02^{* *}$ \\
\hline $\mathrm{RBC} * 10^{6} / \mu \mathrm{L}$ & $9.36 \pm 0.46$ & $7.29 \pm 0.36$ & $8.79 \pm 0.44$ & $8.42 \pm 0.42$ \\
\hline $\mathrm{HGB}$ g/dL & $13.40 \pm 0.67$ & $10.70 \pm 0.53$ & $13.00 \pm 0.65$ & $11.30 \pm 0.56$ \\
\hline HCT \% & $45.80 \pm 2.29$ & $36.30 \pm 1.81$ & $45.00 \pm 2.25$ & $42.50 \pm 2.12$ \\
\hline MCV fL & $48.90 \pm 2.44$ & $49.80 \pm 2.49$ & $51.20 \pm 2.56$ & $51.20 \pm 2.56$ \\
\hline $\mathrm{MCH}$ pg & $14.30 \pm 0.71$ & $14.70 \pm 0.73$ & $14.80 \pm 0.74$ & $14.30 \pm 0.71$ \\
\hline $\mathrm{MCHC} g / \mathrm{dL}$ & $29.30 \pm 1.46$ & $29.30 \pm 1.46$ & $28.90 \pm 1.44$ & $29.20 \pm 1.46$ \\
\hline $\mathrm{PLT} * 10^{5} / \mu \mathrm{L}$ & $7.08 \pm 0.35$ & $11.84 \pm 0.59$ & $6.83 \pm 0.34$ & $8.16 \pm 0.41$ \\
\hline RDW fL & $29.20 \pm 1.46$ & $29.90 \pm 1.49$ & $30.40 \pm 1.52$ & $29.30 \pm 1.46$ \\
\hline PDW fL & $9.10 \pm 0.45$ & $10.40 \pm 0.52$ & $9.00 \pm 0.45$ & $9.10 \pm 0.45$ \\
\hline MPV fL & $7.40 \pm 0.37$ & $7.90 \pm 0.39$ & $6.90 \pm 0.34$ & $7.50 \pm 0.37$ \\
\hline P-LCR \% & $9.80 \pm 0.49$ & $11.90 \pm 0.59$ & $6.10 \pm 0.30$ & $10.20 \pm 0.51$ \\
\hline
\end{tabular}

** showed $P<0.01$ followed by Dunnett's test in comparison to EAC control.

\section{Acknowledgments}

For financial support, the authors thank CCRUM, Department of AYUSH (Ministry of Health and Family welfare) (File no. 3-6/2009-CCRUM/EMR); Dr. Dwarkanth of INMAS, Delhi, is acknowledged for EAC cells, and the DST and UGC are acknowledged for infrastructural facility.

\section{References}

[1] R. L. Siegel, K. D. Miller, and A. Jemal, "Cancer statistics," CA: A Cancer Journal for Clinicians, vol. 65, no. 1, pp. 5-29, 2015.

[2] Z. Wang, "Roles of $\mathrm{K}^{+}$channels in regulating tumour cell proliferation and apoptosis," Pflugers Archiv: European Journal of Physiology, vol. 448, no. 3, pp. 274-286, 2004.

[3] R. Gerl and D. L. Vaux, "Apoptosis in the development and treatment of cancer," Carcinogenesis, vol. 26, no. 2, pp. 263-270, 2005.

[4] T. M. Beer and J. S. Bubalo, "Complications of chemotherapy for prostate cancer," Seminars in Urologic Oncology, vol. 19, no. 3, pp. 222-230, 2001.

[5] R. C. F. Leonard, S. Williams, A. Tulpule, A. M. Levine, and S. Oliveros, "Improving the therapeutic index of anthracycline chemotherapy: focus on liposomal doxorubicin (Myocet)," Breast, vol. 18, no. 4, pp. 218-224, 2009.

[6] C. W. Benjamin, R. R. Hiebsch, and D. A. Jones, "Caspase activation in MCF7 cells responding to etoposide treatment," Molecular Pharmacology, vol. 53, no. 3, pp. 446-450, 1998.

[7] J. Zargan, M. Sajad, S. Umar, M. Naime, S. Ali, and H. A. Khan, "Scorpion (Androctonus crassicauda) venom limits growth of transformed cells (SH-SY5Y and MCF-7) by cytotoxicity and cell cycle arrest," Experimental and Molecular Pathology, vol. 91, no. 1, pp. 447-454, 2011.

[8] B. Patwardhan and M. Gautam, "Botanical immunodrugs: scope and opportunities," Drug Discovery Today, vol. 10, no. 7, pp. 495-502, 2005.

[9] T. Sidiq, A. Khajuria, P. Suden et al., "Possible role of macrophages induced by an irridoid glycoside (RLJ-NE-299A) in host defense mechanism," International Immunopharmacology, vol. 11, no. 1, pp. 128-135, 2011.

[10] O. Kayser, K. N. Masihi, and A. F. Kiderlen, "Natural products and synthetic compounds as immunomodulators," Expert Review of Anti-Infective Therapy, vol. 1, no. 2, pp. 319-335, 2003.

[11] P. Anand, A. B. Kunnumakkara, K. B. Harikumar, K. S. Ahn, V. Badmaev, and B. B. Aggarwal, "Modification of cysteine residue in $\mathrm{p} 65$ subunit of nuclear factor $-\kappa \mathrm{B}(\mathrm{NF}-\kappa \mathrm{B})$ by picroliv suppresses NF- $\kappa \mathrm{B}$-regulated gene products and potentiates apoptosis," Cancer Research, vol. 68, no. 21, pp. 8861-8870, 2008.

[12] V. Rajkumar, G. Guha, and R. A. Kumar, "Antioxidant and antineoplastic activities of Picrorhiza kurroa extracts," Food and Chemical Toxicology, vol. 49, no. 2, pp. 363-369, 2011.

[13] A. Russo, A. A. Izzo, V. Cardile, F. Borrelli, and A. Vanella, "Indian medicinal plants as antiradicals and DNA cleavage protectors," Phytomedicine, vol. 8, no. 2, pp. 125-132, 2001.

[14] A. Ray, S. R. Chaudhuri, B. Majumdar, and S. K. Bandyopadhyay, "Antioxidant activity of ethanol extract of rhizome of Picrorhiza kurroa on indomethacin induced gastric ulcer during healing," Indian Journal of Clinical Biochemistry, vol. 17, no. 2, pp. 44-51, 2002.

[15] A. A. Patil, B. S. Sachin, D. B. Shinde, and P. S. Wakte, "Supercritical $\mathrm{CO}_{2}$ assisted extraction and LC-MS identification 
of picroside i and picroside II from Picrorhiza kurroa," Phytochemical Analysis, vol. 24, no. 2, pp. 97-104, 2013.

[16] S. S. Tiwari, M. M. Pandey, S. Srivastava, and A. Rawat, "TLC densitometric quantification of picrosides (picroside-I and picroside-II) in Picrorhiza kurroa and its substitute Picrorhiza scrophulariiflora and their antioxidant studies," Biomedical Chromatography, vol. 26, no. 1, pp. 61-68, 2012.

[17] T. Kawoosa, H. Singh, A. Kumar et al., "Light and temperature regulated terpene biosynthesis: hepatoprotective monoterpene picroside accumulation in Picrorhiza kurrooa," Functional \& Integrative Genomics, vol. 10, no. 3, pp. 393-404, 2010.

[18] H. Stuppner and H. Wagner, "New cucurbitacin glycosides fom Picrorhiza kurrooa," Planta Medica, vol. 55, no. 6, pp. 559-563, 1989.

[19] S. Sturm and H. Stuppner, "Analysis of cucurbitacins in medicinal plants by high-pressure liquid chromatography-mass spectrometry," Phytochemical Analysis, vol. 11, no. 2, pp. 121-127, 2000.

[20] N. Sindhu, T. Pratima, and W. Ashwini, "Isolation of a cucurbitacin from Picrorhiza Kurroa by column chromatography and its characterization," Research Journal of Pharmaceutical, Biological and Chemical Sciences, vol. 2, no. 3, pp. 149-156, 2011.

[21] F. Engels, B. F. Renirie, B. A. Hart, R. P. Labadie, and F. P. Nijkamp, "Effects of apocynin, a drug isolated from the roots of Picrorhiza kurroa, on arachidonic acid metabolism," FEBS Letters, vol. 305, no. 3, pp. 254-256, 1992.

[22] Y. Kong, J. Chen, Z. Zhou, H. Xia, M.-H. Qiu, and C. Chen, "Cucurbitacin e induces cell cycle G2/M phase arrest and apoptosis in triple negative breast cancer," PLoS ONE, vol. 9, no. 7, Article ID e103760, 2014.

[23] A. A. Alghasham, "Cucurbitacins-a promising target for cancer therapy," International Journal of Health Sciences, vol. 7, no. 1, pp. 77-89, 2013.

[24] A. Aribi, S. Gery, D. H. Lee et al., “The triterpenoid cucurbitacin $\mathrm{B}$ augments the antiproliferative activity of chemotherapy in human breast cancer," International Journal of Cancer, vol. 132, no. 12, pp. 2730-2737, 2013.

[25] S. Duangmano, P. Sae-Lim, A. Suksamrarn, F. E. Domann, and P. Patmasiriwat, "Cucurbitacin B inhibits human breast cancer cell proliferation through disruption of microtubule polymerization and nucleophosmin/B23 translocation," BMC Complementary Alternative Medicine, vol. 12, article 185, 12 pages, 2012.

[26] J.-S. Zhu, D.-Y. Ouyang, Z.-J. Shi, L.-H. Xu, Y.-T. Zhang, and X.-H. He, "Cucurbitacin B induces cell cycle arrest, apoptosis and autophagy associated with $\mathrm{G}$ actin reduction and persistent activation of cofilin in Jurkat cells," Pharmacology, vol. 89, no. 56, pp. 348-356, 2012.

[27] J.-J. Li, Y.-T. Zhang, D.-Y. Ouyang, L.-H. Xu, H.-B. Mo, and X.-H. He, "Suppression of STAT3 phosphorylation enhances the cytotoxicity of cucurbitacin B in B16F10 melanoma cells," African Journal of Pharmacy and Pharmacology, vol. 6, no. 21, pp. 1545-1554, 2012.

[28] C. Boykin, G. Zhang, Y.-H. Chen et al., "Cucurbitacin IIa: a novel class of anti-cancer drug inducing non-reversible actin aggregation and inhibiting survivin independent of JAK2/STAT3 phosphorylation," British Journal of Cancer, vol. 104, no. 5, pp. 781-789, 2011.

[29] K. T. Chan, F. Y. Meng, Q. Li et al., "Cucurbitacin B induces apoptosis and S phase cell cycle arrest in BEL-7402 human hepatocellular carcinoma cells and is effective via oral administration," Cancer Letters, vol. 294, no. 1, pp. 118-124, 2010.
[30] A. C. de Almeida, O. C. Marques, C. Arslanian, A. CondinoNeto, and V. F. Ximenes, “4-Fluoro-2-methoxyphenol, an apocynin analog with enhanced inhibitory effect on leukocyte oxidant production and phagocytosis," European Journal of Pharmacology, vol. 660, no. 2-3, pp. 445-453, 2011.

[31] C. J. Henrich, C. L. Thomas, A. D. Brooks et al., "Effects of cucurbitacins on cell morphology are associated with sensitization of renal carcinoma cells to TRAIL-induced apoptosis," Apoptosis, vol. 17, no. 1, pp. 79-89, 2012.

[32] S. Yasuda, S. Yogosawa, Y. Izutani, Y. Nakamura, H. Watanabe, and T. Sakai, "Cucurbitacin B induces G2 arrest and apoptosis via a reactive oxygen species-dependent mechanism in human colon adenocarcinoma SW480 cells," Molecular Nutrition \& Food Research, vol. 54, no. 4, pp. 559-565, 2010.

[33] Y. Dong, B. Lu, X. Zhang et al., "Cucurbitacin E, a tetracyclic triterpenes compound from Chinese medicine, inhibits tumor angiogenesis through VEGFR2-mediated Jak2-STAT3 signaling pathway," Carcinogenesis, vol. 31, no. 12, pp. 2097-2104, 2010.

[34] D. Rathee, M. Thanki, S. Bhuva, S. Anandjiwala, and R. Agrawal, "Iridoid glycosides-Kutkin, Picroside I, and Kutkoside from Picrorrhiza kurroa Benth inhibits the invasion and migration of MCF-7 breast cancer cells through the down regulation of matrix metalloproteinases," Arabian Journal of Chemistry, vol. 6, no. 1, pp. 49-58, 2013.

[35] R. Parveen, F. J. Ahmad, Z. Iqbal, M. Singh, Y. T. Kamal, and S. Ahmad, "Simultaneous estimation of anti-cancer terpenoids in pharmaceutical nanoformulation by RP-HPLC and HPTLC," Acta Chromatographica, vol. 26, no. 2, pp. 391-400, 2014.

[36] Y. T. Kamal, S. M. Musthaba, M. Singh et al., "Development and validation of HPLC method for simultaneous estimation of piperine and guggulsterones in compound Unani formulation (tablets) and a nanoreservoir system," Biomedical Chromatography, vol. 26, no. 10, pp. 1183-1190, 2012.

[37] Pharmacopoeia of India, Ministry of Health, Government of India, 2nd edition, 1966.

[38] R. Asirvatham and A. J. M. Christina, "Anticancer activity of Drosera indica L., on Dalton's Lymphoma Ascites (DLA) bearing mice," Journal of Intercultural Ethnopharmacology, vol. 2, no. 1, pp. 9-14, 2013.

[39] R. Parveen, F. J. Ahmad, Z. Iqbal, M. Samim, and S. Ahmad, "Solid lipid nanoparticles of anticancer drug andrographolide: formulation, in vitro and in vivo studies," Drug Development and Industrial Pharmacy, vol. 40, no. 9, pp. 1206-1212, 2014.

[40] M. I. Sriram, S. B. M. Kanth, K. Kalishwaralal, and S. Gurunathan, "Antitumor activity of silver nanoparticles in Dalton's lymphoma ascites tumor model," International Journal of Nanomedicine, vol. 5, no. 1, pp. 753-762, 2010.

[41] V. Zuco, R. Supino, S. C. Righetti et al., "Selective cytotoxicity of betulinic acid on tumor cell lines, but not on normal cells," Cancer Letters, vol. 175, no. 1, pp. 17-25, 2002.

[42] Y. T. Ho, C. C. Lu, J. S. Yang et al., "Berberine induced apoptosis via promoting the expression of caspase-8, 9 and 3, apoptosisinducing factor and endonuclease G in SCC-4 human tongue squamous carcinoma cancer cells," Anticancer Research, vol. 29, no. 10, pp. 4063-4070, 2009.

[43] N. Armania, L. S. Yazan, S. N. Musa et al., "Dillenia suffruticosa exhibited antioxidant and cytotoxic activity through induction of apoptosis and G2/M cell cycle arrest," Journal of Ethnopharmacology, vol. 146, no. 2, pp. 525-535, 2013. 



\section{Hindawi}

Submit your manuscripts at

http://www.hindawi.com
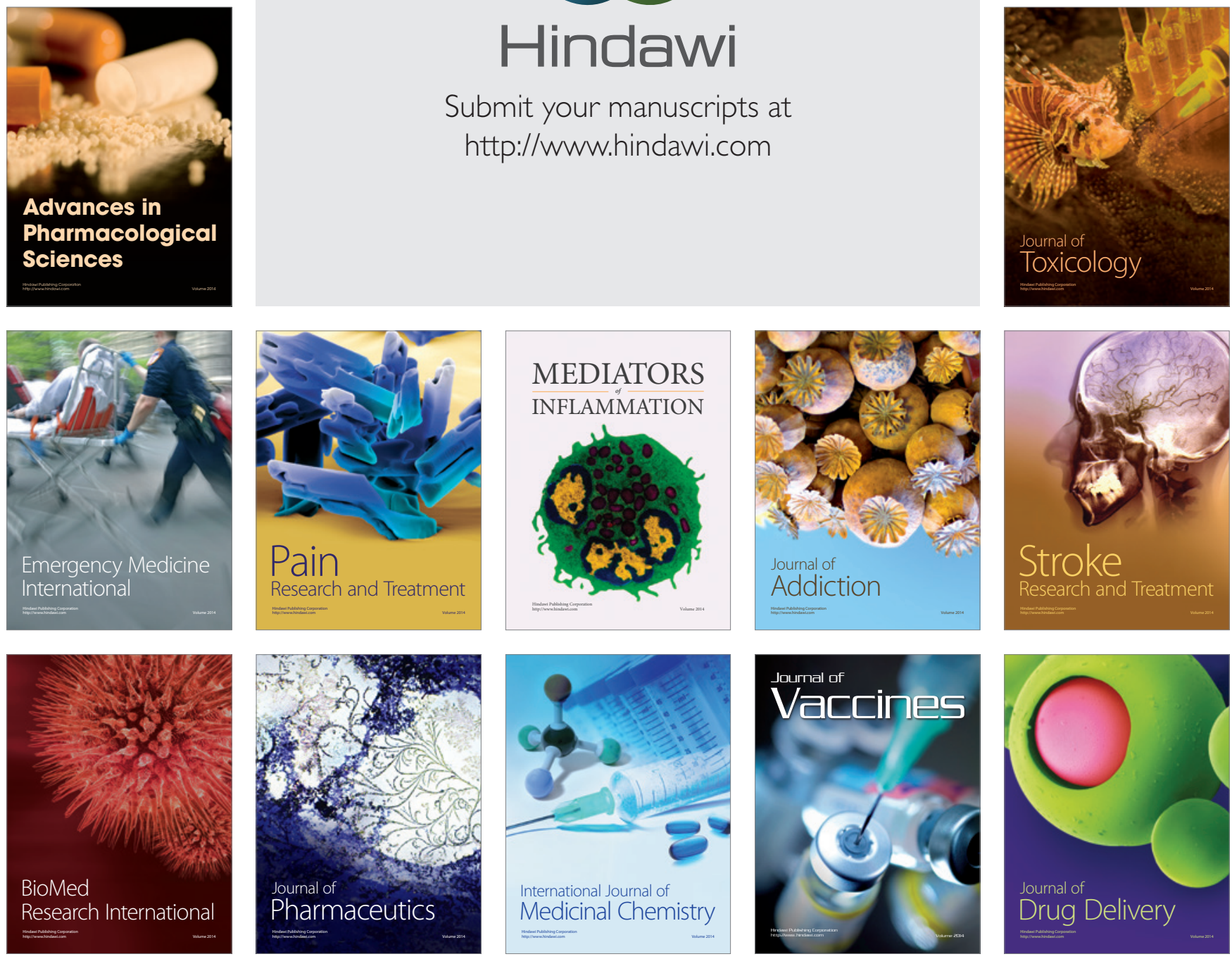